\title{
Mean reversion in long-horizon real exchange rates: Evidence from Latin America ${ }^{\text {is }}$
}

\author{
Pablo Astorga \\ Institut Barcelona de Estudis Internacionals (IBEI), Elisabets 10, 08001 Barcelona, Spain
}

JEL classification:

F41

F31

N16

011

Keywords:

Real exchange rates

Purchasing power parity

Mean reversion

Economic development

Latin America

\begin{abstract}
A B S T R A C $T$
This paper examines mean reversion in real effective exchange rates in six leading Latin American economies during the XXth century using a new data set. A unit-root approach is complemented by an error-correction model including key fundamentals such as terms of trade, trade openness and relative productivities. Unit-root testing shows a very slow process of reversion - if any - to a constant mean in the original series, rejecting the strict PPP hypothesis; however, mean reversion is found after allowing for trends and structural breaks with a halflife average of $1 \frac{1 / 2}{2}$ years for the six countries. We also found reversion to a conditional mean defined by the co-integrating relationship with an average half-life of $2 \frac{1}{2}$ years. Our estimates, although lower than the 3-5 year range that motivated the Rogoff's puzzle, still indicate the presence of important obstacles to the adjustment process that need further investigation.
\end{abstract}

(c) 2012 Elsevier Ltd. All rights reserved.

\section{Introduction}

Long-run quantitative research on countries of the periphery remains an exotic subject: both interesting and elusive. Interesting by virtue of these countries' distinct features, varied experiences and, somehow, from a combination of failure and success in their development efforts. Elusive as a consequence of data limitations. For such countries "periphery" denotes a double condition. On the one hand, it describes their subordinate position in the world economic system and, on the other hand,

\footnotetext{
论 I am grateful to Valpy FitzGerald, Leandro Prados de la Escosura, Marcelo Abreu, Juan Dolado, Jesús Gonzalo, Rui Estevez, Carlos E. Posada, José Díaz, Rolf Lüders, Sebastian Edwards, Antonio Tena Junguito, Luis Boscán, Gustavo Trujillo and two anonymous referees for help and comments.

E-mail address: pastorga@ibei.org.
} 
refers to a relatively marginal attention paid to them by economic studies, particularly those focusing on the long term.

The revival of research on the behaviour of real exchange rates (RER) over a long time horizon conforms to this situation. One key concern of such research is assessing the validity of the Purchasing Power Parity (PPP) as an equilibrium condition for the nominal exchange rate. ${ }^{1}$ The PPP doctrine requires that real exchange rates exhibit mean reversion. That is, that the impact of shocks should be temporary, and that, in the absence of further disturbances, the RER should move back towards its mean value. Recent unit-root studies (which conditioned the real exchange rate on its lagged values) covering a time span of over a century or more, largely in developed economies, have supported the PPP hypothesis by finding mean reversion in real exchange rate series. Mark Taylor (2003) provides a relatively recent survey on this empirical work. Meanwhile, Alan Taylor (2002) extended the long-run analysis to a set of twenty countries and also found support for PPP - although after allowing for deterministic trends in a number of cases. This outcome is at odds with most of the evidence coming out of the analysis during the post Bretton Woods period dominated by the floating of the major currencies (Adler and Lehmann, 1983; Enders, 1988).

A commonly-used measure of the speed of mean reversion is the half-life of the process. ${ }^{2}$ The prevailing consensus in the long-span and panel unit-root studies focusing on industrialised economies is that the half-life process of real exchange rates (in levels) ranges between 3 and 5 years (Rogoff, 1996; and Frankel and Rose, 1996), an outcome that motivated the Rogoff's puzzle. ${ }^{3}$ However, this apparent slow speed of reversion can be caused in part by trend behaviour or/and the presence of one or more structural breaks, implying the absence of a constant mean for the entire period (i.e., a departure from the strict PPP hypothesis). For instance, Taylor (2002) reports half-lives for the detrended series in the range of 2-3 years, while Lothian and Taylor (2008), after allowing for shifts in the equilibrium dollar-sterling real rate over two centuries, suggest that the half-life deviations from PPP may be as low as $2 \frac{1}{2}$ years (compared to 6 years in the original series). Also, Hegwood and Papell (1998) found in their long-span study of six RER series (all from OECD economies) that reversion to the changing mean is much faster than reversion to a fixed mean. After accounting for structural breaks, they estimated half-life values of between 0.5 and $2 \frac{1}{2}$ years.

In recent years the possibility that the RER adjustment process may be non-linear has increasingly received attention by researchers (e.g., Taylor et al., 2001; Sager, 2006). For instance, deviations from parity can persist in the presence of transaction costs affecting the arbitrage of international goods, while large deviations will be offset. In addition, non-linearity implies that adjustments to large deviations from equilibrium are made quicker (e.g., because it increases the likelihood of an intervention from the monetary authority) whilst small deviation can be more persistent. This seems to be particularly relevant for the case of pegged regimes (Taylor, 2004).

The inclusion of trends and shifts in the unit-root studies can be interpreted as the need to account for systematic movements of the equilibrium RER (i.e., departing from the constant mean assumption) which may reflect the action of fundamentals (Lothian and Taylor, 2008; Taylor, 2002). The empirical modelling of the role of fundamentals usually involves the use of a co-integration equation to capture the long-run equilibrium and the associated error-correction specification (ECM) to estimate the speed of adjustment (in this case to time-varying equilibrium). ${ }^{4}$ For instance, using this approach, Clark and MacDonald (1998) in their analysis of the US dollar exchange rate system (including rates to seven key trading partners) during the period 1960-1996 found that when deviations are measured relative to a changing RER equilibrium a much faster mean reversion results with $40 \%$ of the gap between the actual and the equilibrium rate closed within a year (equivalent to half-life values of about $1 \frac{1 / 2}{2}$ years.

\footnotetext{
${ }^{1}$ In its absolute version, PPP states that the equilibrium nominal exchange rate between two countries will equal the ratio of the countries' price levels. In its relative version it states that the nominal exchange rate equilibrium will change according to the relative change in the countries' price levels.

2 The number of years that it takes for deviations from equilibrium to subside permanently below 0.5 in response to a unit shock in the level of the series.

${ }^{3}$ Rogoff (1996) argues that the estimated speed of adjustment of real exchange rates is difficult to justify in terms of wage or price stickiness, or shocks related to real factors such as technology or tastes.

${ }^{4}$ See MacDonald (1998) for a survey.
} 
And in a study covering commodity-dependent (mostly developing) countries for the more recent period of 1980-2002 (with monthly data), Cashin et al. (2004) found that the average speed of mean reversion comes down from 3 years when unit-root procedure is used to measure reversion to a constant mean, to about one year using an EMC with the real commodity price as key fundamental.

The fact that long-span studies of mean reversion have largely focused on developed economies raises questions as to the extent to which their findings are confirmed by the behaviour of RER in countries that have failed to join the developed club. Most multi-country studies on developing countries relating to real exchange rates concentrates on the second half of the XXth century (e.g., Edwards, 1989; Wood, 1991; Baffes et al., 1999; Joyce and Kamas, 2003; Cashin et al., 2004) ${ }^{5}$; a choice of period largely determined by limited availability of comparable data. Moreover, this shortage of evidence, as Froot and Rogoff, 1995 have pointed out, creates the possibility of a "survivors" bias in the recent findings using long-span series. ${ }^{6}$ That is, that the propensity of the RER series to revert to a constant mean might be exaggerated by the inclusion of wealthy countries, or economies that already displayed high living standards at the start of the last century. Indeed, there are various ways in which the dynamics associated with economic development can affect the RER stability around a constant mean in the long term. The most prominent is via productivity differentials as captured by the Balassa-Samuelson model (hereinafter B-S). ${ }^{7}$ Other fundamentals shaping the formation of relative prices are the terms of trade, openness to international trade, and capital flows (Edwards, 1989; Montiel, 1999; Neary, 1988).

This paper examines RER mean reversion in the long term in six Latin American economies (LA6) ${ }^{8}$ : Argentina, Brazil, Chile, Colombia, Mexico, and Venezuela during the period 1900-2000. First, it tests the case of mean reversion using a unit-root (univariate) approach - allowing for structural breaks and trend behaviour, making it possible to compare the results with other studies that examine the PPP hypothesis with long-span data. Secondly, it makes a systematic attempt to incorporate within an ECM framework fundamental variables - including relative productivities, terms of trade, trade openness, and real government spending - with the potential to shape the equilibrium real exchange rates in the LA6. ${ }^{9}$ This multivariate approach offers an alternative measure of RER reversion, this time to a conditional mean defined by a co-integrating equation.

The starting point of our task is the creation of a consistent dataset of multilateral or effective real exchange rates (REER) over the whole century. Although there are available long-term real exchange rate series for a number of Latin American countries, they are largely bilateral rates with the US. This introduces a bias, particularly in the early and late decades of the last century characterised by a more geographically diversified trade structure. We also construct comparable series across the LA6 of four RER fundamentals to make possible the estimation of the ECM. The use of this new dataset for the longrun study of RER in the LA6 is a novelty of this work.

The remainder of the paper is structured as follows. Section 2 introduces the RER empirical measure used and gives details on the procedure used to construct the corresponding multilateral indices. Section 3 tests for non-stationarity and calculates the half-time values of mean reversion in the REER series adopting a unit-root approach. Section 4 follows a co-integrating procedure to assess the role of fundamental forces and estimate the speed of mean reversion to a time-varying equilibrium. It also offers a comparison between the two sets of half-life estimates. Finally, there is a section of conclusions. An Appendix includes an outline of trade policy changes, exchange rate regimes and the inflation record for the six countries over the century, and our REER series, as well as data sources.

\footnotetext{
${ }^{5}$ An exception is Taylor (2002) who includes Argentina, Brazil, and Mexico in his panel data of twenty countries covering more than 100 years, but he uses bilateral rates and the sample is dominated by developed countries. Also the lack of testing for structural breaks - and, if necessary, correcting for them - has the potential to undermine his assessment of stationarity.

${ }^{6}$ The term may be somehow misleading, as the countries included more than "survivors" are "successful" cases in terms of the development outcome.

7 The main prediction is that if the labour productivity of a given country in producing tradable goods relative to their productivity in producing non-tradable goods grows faster than abroad, then the country's currency will appreciate in real terms. The seminal contributions are Balassa (1964) and Samuelson (1964).

8 These countries have accounted for about $80 \%$ of Latin America's GDP and population over the last century. Their selection is also partly justified by data availability, particularly regarding series of key fundamentals such as relative productivity.

${ }^{9}$ This approach is akin to the econometric analysis of the behaviour of RER (BEER) favoured by Clark and MacDonald (1998).
} 


\section{Multilateral real exchange rate indices}

As in most of the empirical literature dealing with the RER and, particularly, in long-span studies, we define the RER as a measure of relative purchasing power between two countries:

$$
\mathrm{RER}=E \frac{P_{C}^{*}}{P_{C}}
$$

where $E$ stands for the nominal exchange rate (domestic currency per unit of foreign currency), $P_{C}$ denotes the consumer price index (CPI) at home, and $P_{c}^{*}$ the CPI in the comparator country. This is also known as the symmetric definition. ${ }^{10}$

Based on (1) we construct a multilateral real exchange rate indices (REER) for each of the LA6 countries (see Table A2 in the Appendix). An increase in the value of the real exchange rate indicates real depreciation, whereas a fall shows a real appreciation of the domestic currency. The indices are calculated as geometric weighted averages of bilateral real exchange rates as in Chinn (2006) using the following formula:

$$
\operatorname{REER}_{j t}=\sum_{i=1}^{k} \omega_{i t} R E R_{i t}
$$

where: REER $_{j t}$ is the index of multilateral or effective real rate (in logs) for country $j$ in period $t(j=1-6$; $t=1-100)$. $\omega_{i t}$ is the weight corresponding to trade partner $i$ in period $t$. The weights applied to calculate the effective or multilateral indices are import shares calculated annually (in value terms). ${ }^{11}$ At least six main trade partners (US, UK, Germany, France, Japan, and one or two Latin American economies) are included. ${ }^{12}$ RER $_{i t}$ is the bilateral real exchange rate (in logs) between country $j$ and country $i$. Bilateral real rates with countries other than the US are derived as cross rates from the corresponding US dollar series.

The bilateral nominal exchange rate used to calculate our indices refers to the rate applicable to imports - or to averages, when multiple rates (MER) were in place. At different times, the LA6 countries adopted various exchange rate regimes, ranging from the gold and gold-exchange standard, fixed, multiple rates (with many variations), ${ }^{13}$ crawling pegs, and, more recently, floating rates. But, overall, exchange regimes with a fixed or a controlled rate for most transactions in the trade account were the norm. The LA6 economies were under some sort of pegged regime (fixed, multiple or dual regimes) for more than $70 \%$ of the time in the last century. Floating arrangements - with convertible currencies - were rarely implemented, featuring mostly in the 1990 s with the adoption of inflation targeting (see Table A1). ${ }^{14}$

In those instances where there was a unified rate, or a dual regime with an official (usually fixed) rate applied to most current account transactions and a "free" or market-determined rate to convert capital transactions, the selection of the appropriate rate has fewer complications. In the case of multiple exchange rates, wherever possible, we are working with an average of those rates applied to

\footnotetext{
${ }^{10}$ CPIs are chosen over GDP deflators, which provide a more general index, because of their availability for the LA6 during the whole period.

${ }^{11}$ Export shares tend to match those of imports in our sample of countries with the exception of Argentina and, to an extent Brazil, during the decades before the Great Depression where trade and capital flows were characterised by a triangular structure: imports from the US and exports to the UK (O'Connell, 1984). We performed a sensitivity analysis for Argentina using weights calculated over all traded goods and the resulting REER series shows no significant changes relative to those calculated with imports shares only.

12 Our sample of trading partners covers about 70\% of imports up to the 1960 s. Thereafter the average share falls to about $60 \%$, reflecting a more diversified trade structure. However, despite the narrowing of the coverage, our multilateral series during the period 1980-2000 behave in line with those constructed by the Centro de Economía Internacional (CEI), which encompass 23 trading partners covering at least $80 \%$ of trade flows.

${ }^{13}$ These were used prominently in the 1940s and, especially, 1950s in Argentina, Brazil, Chile and Colombia as an instrument of trade policy - with tariffs relegated to a secondary place as they lost efficiency owing to the introduction of trade treaties (Macario, 1964).

${ }^{14}$ We do not discriminate between regimes in this work as this would undermine significantly the power of the tests. However, this is a main issue in the literature (e.g., Taylor, 2002; Parsley and Popper, 2001).
} 
import transactions. When the data are available (e.g., Colombia and Chile), the average is weighted by the different trade flows associated with each rate. But in the face of data limitations, we are taking simple averages (e.g., Venezuela during 1961-1964 and 1983-1989). These limitations in calculating weighted average rates when MERs were in place may be a source of distortions. ${ }^{15}$ Multiple rates applied to exports - which prices, in many cases, had little impact on domestic prices - are mostly ignored. However, they were a common feature in some of the LA6 countries during the period.

Regarding internal price dynamics, despite the reputation of being an inflation-prone region, nearly $80 \%$ of the time inflation was under control or the countries underwent periods of deflation. This was the typical adjustment mechanism under the gold standard, and was common in the years prior to the Great Depression. According to our calculations, deflation was a feature in Argentina and Mexico during the 1920s and the early 1930s. Brazil and Colombia also experienced deflation during this period and earlier in the century. However, our sample includes countries such as Argentina, Brazil and Chile that endured recurrent episodes of hyperinflation during the 1970s and 1980s and changes in currencies, vis-à-vis Venezuela and post-revolutionary Mexico, both characterised by a higher degree of price and exchange rate stability. As with the case of MERs, hyperinflation episodes have the potential to bring about distortions in the RER adjustment process, and we will control for both factors in the regression analysis in Section 4.

\section{Mean reversion under a univariate approach}

The empirical literature dealing with the testing for long-run PPP usually relies on the augmented Dickey-Fuller test (ADF) for unit root in the process driving the real exchange rate. The rejection of the null hypothesis that a time series follows a random walk - the archetypal non-mean reverting process - is taken as evidence of mean reversion (Taylor, 2003). The application of the unit-root tests - ADF and Phillips-Perron (PP) - to our REER series in levels (logs) cannot reject the null hypothesis in any of the cases (results not shown). This indicates that the series in levels are non-mean reverting to a constant mean; a result that is at odds with the message from recent studies with long-span data. The failure to reject the unit-root hypothesis can be owing to the presence of trends or structural breaks in the series. Once a simple linear trend is included, the unit-root test performed over the de-trended series (e.g., the residuals of the regression with a time trend and a constant) still fails to reject the null hypothesis in most cases at the $5 \%$ level. But we still need to allow for the possibility of structural breaks in the series, before concluding that they are non-stationary (Perron, 1989, 1990).

\subsection{Structural breaks}

We adopt the methodology proposed by Zivot and Andrews (1992) - hereinafter Z\&A - to determine endogenous structural breaks. A test statistic is calculated in each period, allowing for the possibility of breaks in the intercept, the slope, or both. If the minimum test value is below (i.e., higher in absolute value) a given critical level, it implies that the non-stationarity of the series is due to the presence of a structural break. ${ }^{16}$ In order to identify potential multiple break points, we follow a sequential search on the lines suggested by Bai and Perron (1998). However, the power of the test declines sharply once the sample is subdivided. Table 1 presents the outcome of testing for structural breaks. It informs about the years where a minimum is identified, the test values, and the type of break. When applying the Z\&A test to the REER series the null hypothesis of unit root is rejected at the $10 \%$ level or lower in eleven cases, involving Argentina, Brazil, Colombia, Mexico, and Venezuela. The test

\footnotetext{
${ }^{15}$ Consider a simplified situation of a country with a multiple regime with two fixed rates: a lower rate of 1 peso per dollar (P) that covers $40 \%$ of import transactions (e.g., medicines and food); and a higher rate P2 applied to the remaining $60 \%$. The weighted average exchange rate is P1.6, but suppose we use the simple average of P1.5 as a representative rate. Now the government decides to reduce the share of imports covered by the lower rate to $20 \%$, in which case the new weighted rate goes up to P1.8; an implicit devaluation of $12.5 \%$. This move is likely to trigger some inflation, let's say of $12.5 \%$. In this case the "true" real exchange rate stays unchanged (assuming no foreign inflation), but the simple average RER would show a $12.5 \%$ appreciation as there is no change in the nominal rates.

${ }^{16}$ We use a program written by Trujillo (2006) in EViews to implement the Z\&A test. The program is available on request.
} 
Table 1

Indentification of break points Zivot \& Andrews testing procedure.

\begin{tabular}{|c|c|c|c|c|c|c|c|c|c|}
\hline & \multicolumn{3}{|l|}{ REER } & \multicolumn{2}{|l|}{ TofT } & \multicolumn{2}{|l|}{ Open } & \multicolumn{2}{|c|}{ Rprodm } \\
\hline & Year & $t$-stat ${ }^{\mathrm{a}}$ & Type & Year & Type & Year & Type & Year & Type \\
\hline \multirow[t]{3}{*}{ Argentina } & 1952 & $5.30 * * *$ & $m \varepsilon t$ & & & 1940 & $m$ & & \\
\hline & $1955 / 85$ & $3.30 / 4.62 * *$ & $t$ & 1976 & $t$ & 1972 & $t$ & 1970 & $m \varepsilon t$ \\
\hline & 1985 & $4.51 * * *$ & $m$ & & & & & & \\
\hline \multirow[t]{2}{*}{ Brazil } & 1944 & $4.73 * *$ & $t$ & 1914 & $m \varepsilon t$ & 1942 & $m$ & & \\
\hline & 1944 & 4.71 & $m \varepsilon t$ & 1950 & $m \varepsilon t$ & 1990 & $t$ & 1958 & $m \varepsilon t$ \\
\hline \multirow[t]{2}{*}{ Chile } & 1945 & 4.27 & $m$ & 1930 & $m$ & 1931 & $m$ & & \\
\hline & 1947 & 4.49 & $m \varepsilon t$ & 1975 & $m$ & 1974 & $m \varepsilon t$ & 1980 & $t$ \\
\hline \multirow[t]{3}{*}{ Colombia } & 1923 & $4.73 *$ & $m$ & 1915 & $t$ & & & & \\
\hline & 1958 & $4.60 * *$ & $t$ & 1948 & $t$ & 1956 & $m$ & 1983 & $t$ \\
\hline & 1957 & $4.85 *$ & $m \varepsilon t$ & 1958 & $m$ & & & & \\
\hline \multirow[t]{3}{*}{ Mexico } & 1917 & $4.58 *$ & $m$ & & & $1914^{\mathrm{b}}$ & $m \varepsilon t$ & & \\
\hline & 1917 & $4.25 *$ & $t$ & 1977 & $m$ & 1988 & $t$ & 1974 & $t$ \\
\hline & 1932 & $5.2 * *$ & $m \varepsilon t$ & & & & & & \\
\hline \multirow[t]{2}{*}{ Venezuela } & 1961 & $4.24 *$ & $t$ & 1973 & $m$ & 1925 & $m$ & 1982 & $t$ \\
\hline & 1961 & 4.33 & $m \varepsilon t$ & & & 1961 & $t$ & & \\
\hline
\end{tabular}

$m$ : break in the mean; $t=$ break in the trend; $m \varepsilon t=$ break in the mean and trend. *,**, \&*** indicate that the critical value is rejected at the $10 \%, 5 \%$, and $1 \%$ levels, respectively. Critical values for $t$ are from Perron (1990); and for $m$ and $m \varepsilon t$ from Perron and Vogelsang (1993). To improve the power of the test we extend the sample period until 2005.

a all test values are negative.

b sample 1900-1980.

values for Chile fail to reject the null at the $10 \%$ level of significance. However, the probability of not rejecting the unit-root null when it is false is high, even with a long-span of data (Lothian and Taylor, 1996). ${ }^{17}$ For Chile's REER, we decide to include a breakpoint in the mean in 1945, where the test is close to the critical value at $10 \%$ of significance.

Table 1 also presents information about the presence of major discontinuities in key fundamentals, namely: terms of trade (TofT), the country's productivity in manufacturing relative to the US (Rprodm), and the gross trade ratio (Open) as a proxy for trade policy. Although the link between REER and the fundamentals will be explored with more rigour in Section 3, a simple comparison on the date breaks shows that a number breaks in REERs can be associated with an unusual near event in either the terms of trade, openness, or relative productivities. This is particularly the case in Brazil, Colombia, Mexico, and Venezuela. However, it is not the case that all breaks in fundamentals have a corresponding REER one (e.g., terms of trade circa 1930 in Chile), nor do all REER breaks have a matching discontinuity in any of the three fundamentals (e.g., Argentina in 1952). The former suggests that - notwithstanding statistical limitations - joint effects (including offsetting moves, for instance, in the form of capital flows to cushion an external shock) are important in triggering or avoiding a major break in the real exchange rate; whereas the latter points to the need to include additional variables or relevant events.

\subsection{Testing for non-stationarity}

We follow the two-stage procedure to test for non-stationarity in series with breaks proposed by Perron (2006). A description of this procedure follows.

Consider a trending series generated by $y_{t}=\mu+\beta t+u_{t}$, where:

$$
\Delta u_{t}=C(L) e_{t}
$$

with $e_{t} \sim$ i.i.d. $\left(0, \sigma_{e}^{2}\right)$ and $C(L)=\sum_{j=0}^{\infty} c_{j} L^{j}$ such that $\sum_{j=0}^{\infty} j\left|c_{j}\right|<\infty$ and $c_{0}=1$.

\footnotetext{
${ }^{17}$ Facing this level of type II error, the researcher needs to take a view on whether to make allowances for a break. This decision involves giving more weight to one of the two competing conceptions of the nature of the macroeconomic series. Under a view that favours non-stationarity, lasting shocks to the series can be interpreted as low-probability realisations of a given data-generating process. On the other hand, under the belief that the world is more akin to stationary processes, a sudden and lasting move is seen as a structural break rather than a low-probability event.
} 
Making allowances for a one-time change in the trend function, results in two versions of four different structures: 1) a change in level for a non-trending series; and for trending series, 2) a change in level, 3) a change in slope, and 4) a change in both level and slope. For each of the four cases, two versions allow for different transition effects. The first is labelled the "additive outlier model" (AOM) and specifies that the change to the new trend function occurs instantaneously. The second is the "innovational outlier model" where the change to the new trend function is gradual. We use AOMs because they allow for a joint change in the trend without a break, and in general offer a good description of our series. The AOM specifications for changes at a break date $T_{1}$ are as follows:

$$
\begin{array}{ll}
\text { Model (AO - 0) } & y_{t}=\mu_{1}+\left(\mu_{2}-\mu_{1}\right) D U_{t}+u_{t} \\
\text { Model (AO - A) } & y_{t}=\mu_{1}+\beta t+\left(\mu_{2}-\mu_{1}\right) D U_{t}+u_{t} \\
\text { Model (AO - B }) & y_{t}=\mu_{1}+\beta_{1} t+\left(\beta_{2}-\beta_{1}\right) D T_{t}^{*}+u_{t} \\
\text { Model }(A O-C) & y_{t}=\mu_{1}+\beta_{1} t+\left(\mu_{2}-\mu_{1}\right) D U_{t}+\left(\beta_{2}-\beta_{1}\right) D T_{t}^{*}+u_{t}
\end{array}
$$

where $D U_{t}=1, D T_{t}^{*}=t-T_{1}$ if $t>T_{1}$ and 0 otherwise, and $u_{t}$ is specified by (3). Under the null hypothesis $C(1) \neq 0$, while under the alternative hypothesis, $C(1)=0$.

The test procedure consists of a two-step approach. In the first step, the trend function of the series is estimated and removed from the original series via the following regressions for Models (AO-0) to (AO-C), respectively:

$$
\begin{array}{ll}
(\mathrm{AO}-0) & y_{t}=\mu+\gamma D U_{t}+\tilde{y}_{t} \\
(\mathrm{AO}-\mathrm{A}) & y_{t}=\mu+\beta t+\gamma D U_{t}+\tilde{y}_{t} \\
(\mathrm{AO}-\mathrm{B}) & y_{t}=\mu+\beta t+\gamma D T_{t}^{*}+\tilde{y}_{t} \\
(\mathrm{AO}-\mathrm{B}) & y_{t}=\mu+\beta t+\theta D U_{t}+\gamma D T_{t}^{*}+\tilde{y}_{t}
\end{array}
$$

where $\tilde{y}_{t}$ is accordingly defined as the de-trended series.

The next step differs according to whether or not the first involves $D U_{t}$, the dummy associated with a change in intercept. For Models (AO-0), (AO-A) and (AO-C), the test is based on the value of the $t-$ statistic for testing that $\alpha=1$ in the following autoregression:

$$
\tilde{y}_{t}=\alpha \tilde{y}_{t-1}+\sum_{j=0}^{k} d_{j} D\left(T_{1}\right)_{t-j}+\sum_{i=1}^{k} a_{i} \Delta \tilde{y}_{t-i}+e_{t}
$$

The outcome of the implementation of Perron's procedure is summarised in Table 2. Columns 1 and 2 give the model to be estimated and the breakpoint dates. When more than one break is included, we list them in chronological order. For instance, Brazil's model AO-B\&C, 1914 \& 1944 indicates the inclusion of a trend break in 1914 and a simultaneous break in the mean and trend in 1944. Columns 3-6 present key estimated parameters of the regressions: $\hat{\beta}$ is the estimate of the initial (pre-break) slope of the trend function; $\hat{\theta}_{1}$ and $\hat{\theta}_{2}$ are estimates of the change in the intercept of the trend function; and $\hat{\gamma}_{1}$ and $\hat{\gamma}_{2}$ are estimates of the change in the slope of the trend function (post first break). The trend coefficients indicate annual rates of growth. In the presence of a break in the trend, annual growth in the post-break period results from adding up the initial trend coefficient $\hat{\beta}$ and the $\hat{\gamma}$ s estimates. For example, in the case of Argentina's AO-B (1952) model, the annual trend growth up to 1952 is estimated at $-0.6 \%$. But after 1952 , it changes to $1.2 \%(-0.6 \%-+1.8 \%)$. In column 6 we report the standard error of the regression (SER). Finally, columns 7 and 8 inform on the second stage of the procedure: $\hat{\alpha}$ is the estimate of the autoregressive coefficient of the regression equation with the residuals (see Eq. (4)), and tô is the associated $t$-statistic - we use the ADF test - for testing that $\alpha=1{ }^{18}$ In deciding on which particular model to choose for each country (shaded values), we also assess the SER and favour those specifications that minimises it. But, if the difference is small, we opt for the specification with the minimal number of breaks.

The trend patterns during the first half of the century or so are mixed, with Argentina, Brazil, Colombia and Venezuela displaying a flat or downward trend (i.e., REER appreciation) in our preferred models. However, the second half of the century is dominated by an upward trend (real

\footnotetext{
18 We used a lag parameter of four for the sum of the autoregressive first differences, and a lag of two for the trend dummies (only necessary in models A and C).
} 
Table 2

Non-stationarity test for REER series.

\begin{tabular}{|c|c|c|c|c|c|c|c|c|c|c|}
\hline & \multicolumn{2}{|c|}{ Period 1900-2005 } & \multicolumn{6}{|c|}{ First stage } & \multicolumn{2}{|c|}{ Second stage } \\
\hline & (1) Model & (2) $T b$ & (3) $\hat{\beta}$ & (4a) $\hat{\theta}_{1}$ & (4b) $\hat{\theta}_{2}$ & (5a) $\hat{\gamma}_{1}$ & (5b) $\hat{\gamma}_{2}$ & (6) SER & (7) $\hat{\alpha}$ & (8) $t \hat{\alpha}(\mathrm{ADF})$ \\
\hline \multirow[t]{4}{*}{$\overline{\text { ARG }}$} & $\mathrm{AO}-\mathrm{B}$ & 1952 & -0.006 & & & 0.018 & & 0.187 & & \\
\hline & $\mathrm{AO}-\mathrm{C}$ & 1952 & 0.000 & -0.358 & & 0.017 & & 0.164 & 0.62 & $-3.25 * *$ \\
\hline & AO-B & 1955 & -0.005 & & & 0.019 & & 0.182 & & \\
\hline & $\mathrm{AO}-\mathrm{C} \& \mathrm{~B}$ & $1952 \& 1985$ & 0.000 & -0.306 & & 0.014 & 0.011 & 0.162 & & \\
\hline \multirow[t]{4}{*}{ BRA } & AO-B & 1944 & 0.012 & & & -0.002 & & 0.235 & & \\
\hline & $\mathrm{AO}-\mathrm{C}$ & 1944 & 0.020 & -0.409 & & -0.006 & & 0.213 & 0.64 & $-3.80 * * *$ \\
\hline & $\mathrm{AO}-\mathrm{B} \& \mathrm{C}$ & $1914 \& 1944$ & -0.020 & & -0.587 & 0.053 & -0.020 & 0.193 & 0.59 & $-3.79 * * *$ \\
\hline & $\mathrm{AO}-\mathrm{C}$ & 1953 & 0.009 & 0.120 & & 0.000 & & 0.235 & & \\
\hline \multirow[t]{2}{*}{$\mathrm{CHI}$} & $\mathrm{AO}-\mathrm{A}$ & 1945 & 0.020 & -0.853 & & & & 0.2 & 0.56 & $-4.08 * * *$ \\
\hline & $\mathrm{AO}-\mathrm{C}$ & 1947 & 0.012 & -0.778 & & 0.012 & & 0.182 & & \\
\hline \multirow[t]{2}{*}{$\mathrm{COL}$} & $\mathrm{AO}-\mathrm{B}$ & 1957 & 0.006 & & & 0.015 & & 0.211 & & \\
\hline & $\mathrm{AO}-\mathrm{C}$ & 1957 & 0.002 & 0.263 & & 0.014 & & 0.200 & 0.72 & $-4.38 * * *$ \\
\hline \multirow[t]{4}{*}{ MEX } & AO-B & 1917 & 0.044 & -0.037 & & & & 0.238 & & \\
\hline & $\mathrm{AO}-\mathrm{C}$ & 1932 & 0.024 & 0.327 & -0.023 & & & 0.166 & & \\
\hline & AO- $0 \& 0$ & $1917 \& 1932$ & 0.001 & 0.502 & 0.442 & & & 0.149 & 0.59 & $-4.0^{* * *}$ \\
\hline & $\mathrm{AO}-\mathrm{B} \& \mathrm{C}$ & $1917 \& 1932$ & -0.001 & 0.529 & 0.454 & 0.002 & & 0.115 & & \\
\hline \multirow[t]{2}{*}{ VEN } & AO-B & 1961 & -0.002 & & & 0.017 & & 0.152 & & \\
\hline & $\mathrm{AO}-\mathrm{C}$ & 1961 & -0.005 & 0.322 & & 0.014 & & 0.130 & 0.70 & $-3.18 * *$ \\
\hline
\end{tabular}

Columns 3-5: estimates in bold are significant at least at the 5\% level. SER: standard error of the regression. $\left({ }^{*}\right),\left({ }^{* *}\right)$, and $(* * *)$ indicate that the critical value is rejected at the $10 \%, 5 \%$, and $1 \%$ levels, respectively.

depreciation), with annual trends of $1.7 \%$ after 1952 in Argentina (model AO-C), $1.3 \%$ after 1944 in Brazil (model AO-B\&C), 2\% after 1945 in Chile (model AO-A), 1.4\% after 1957 in Colombia (model AOC), and $0.9 \%$ after 1961 in Venezuela (model AO-C). Mexico shows no trend in model AO-0\&0 (our preferred one) and AO-B\&C, but an upward trend of $2.2 \%$ after 1932 in model AO-C. The behaviour of the final decades confirms the findings of studies covering a much wider sample of developing countries after 1960s (e.g., Wood, 1991). A depreciating trend in the RER is consistent with a lack of economic convergence, a phenomenon that would call for faster productivity growth in those countries attempting to catch up and real exchange rate appreciation over time (as has been the case in economies such as Japan).

\subsection{Half-life results}

All series in the second stage of the procedure are stationary around a trend after allowing for at least one-time structural change. This is evidence of mean reversion in the adjusted series. The upper part of Table 3 presents information about our mean reversion results. First estimates for the autocorrelation coefficients of the de-trended series are presented with the corresponding half-time values for each of the REER series. Then, it includes results after making allowances for changes in the slope and/or the intercept. Note that the half-life estimates obtained with this procedure are best interpreted as the time it takes for disturbances to the RER to dissipate rather than half-life values associated to strict PPP deviations.

The half-life of our de-trended REER series ranges from 21/2 years in Brazil to 7 years in Mexico. This half-life range is similar to those found in more advanced economies (e.g., RER of the dollar-sterling and franc-sterling), but with the crucial difference that the latter tend to be estimated without de-trending the original series. For instance, in their assessment of real exchange rate series spanning two centuries, Lothian and Taylor, 1996 found half-life values of about 6 years and just under 3 years respectively. Thus, the need to de-trend our series in order to remove non-stationarity can be interpreted as a required correction due to the development process (in the spirit of B-S). It may also give an indication of the relevance of the "survivors" bias suggested by Froot and Rogoff. After adjustments for breaks to account for the impact of major discontinuities (e.g., related to lasting changes in fundamentals), our half-life values drop significantly, now with values ranging from 1.2 years in Chile to 2.1 years in Colombia 
Table 3

Speed of mean reversion (unit-root approach).

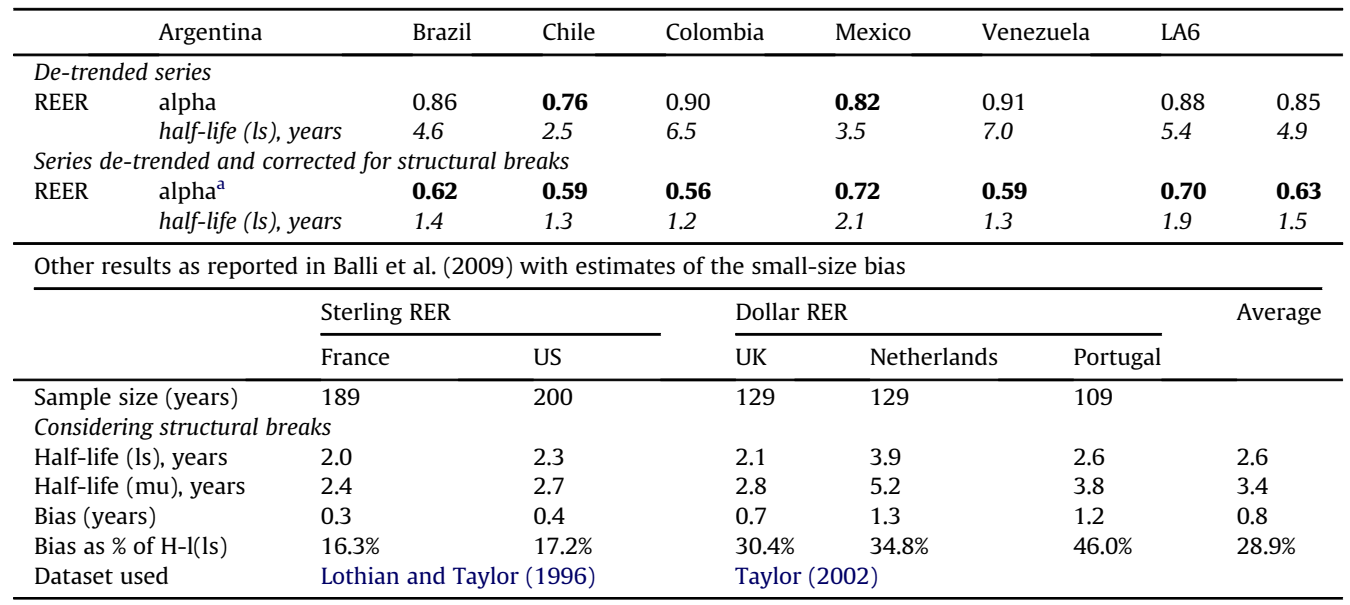

$\mathrm{ls}=$ ordinary least squares estimation; $\mathrm{mu}=$ median-unbiased estimation.

Alpha: autocorrelation coefficient (in bold cases where the unit root is rejected at the $10 \%$ level or lower).

Values in bold are series where the unit root is rejected at the $10 \%$ level or lower.

${ }^{\text {a }}$ Values correspond to autocorrelation estimates reported in Table 2

(with a simple average for the LA6 of $1 \frac{1 / 2}{2}$ years). These values tend to be in the lower part of the range of half-lives reported for developed economies, indicating that once the necessary adjustments are made, the six Latin American countries show a relatively fast speed of mean reversion. However, as Balli et al., 2009 have shown, estimates obtained by ordinary least square estimation (OLS) are subject to a smallsample bias - as documented in Andrews (1993) - resulting in shorter half-lives. Also that the inclusion of structural breaks, although correcting an upward bias, can cause an increase in the small-sample bias. The authors suggest using an extension of a median-unbiased estimation to address this problem.

To give some idea of the potential bias of our half-life values arising by the use of OLS estimation, the lower part of Table 3 presents findings of long-span studies reported in Balli et al. (2009) for trendless series adjusted by structural breaks. It includes the half-life values using least squares and medianunbiased estimation. The average bias for the five series reported is of 0.8 years, corresponding, on average, to about $30 \%$ of the original half-life estimates using OLS. If we use this figure as a reference, our average half-life for the LA6 would rise to about 2 years, which is still within the range of values for adjusted series reported in the literature.

The inclusion of trends and breaks of the unit-root analysis conducted so far acknowledges the need to modify the strict PPP prediction and allow for the possibility of changes in the equilibrium position. However, it says little about the forces causing permanent shifts or trend behaviour in the real exchange rate. For this it is necessary to model explicitly the role of macroeconomic fundamentals driving the RER equilibrium. To this task we turn next.

\section{Reversion to a changing equilibrium: the role of fundamentals}

In order to guide the selection of fundamentals to be included in our analysis, we rely on a dynamic model for a developing economy formulated by Edwards (1989). ${ }^{19}$ The model captures salient features of those economies such as the prominence of exchange controls, trade barriers, and dual exchange rate regimes (usually, a fixed rate for trade transactions and a floating rate for financial transactions).

\footnotetext{
19 Since the purpose of this paper is empirical we only present a brief summary of the model and the expected link between the fundamentals and the RER.
} 
There are three representative goods in the economy: one exportable, one importable and one nontradable. It is assumed that the country produces the exportable and the non-tradable good and consumes the importable and the non-tradable good. The government consumes both importable and non-tradable goods and uses non-distortionary taxes and domestic credit to finance its expenditure. The model is closed with an expression for the real exchange rate defined as the relative price of tradable to non-tradable goods. ${ }^{20}$

The long-run sustainable equilibrium is attained when the market for non-tradable goods and the external sector are simultaneously in equilibrium. The key fundamentals in the model are the terms of trade, trade policy (import tariffs), and real government spending on non-tradable goods. ${ }^{21}$ The direction of the effect of higher import tariffs is ambiguous, but under most plausible conditions they will result in an RER appreciation. An increase in the government consumption of non-tradable goods also should result in a real appreciation. The impact of changes in the terms of trade on relative prices is ambiguous, but there is a strong presumption that a sustained terms of trade increase will result in a real appreciation (Edwards and van Wijnbergen, 1987). This is the case if the income effect - which leads to higher demand for non-tradable goods - dominates the substitution effect associated with a decline in the relative cost of the imported intermediate goods used in the non-tradable sector.

Although not considered in Edward's dynamic model, the productivity differential (accounting for the B-S effect) is recognised both in theory and practice as an important fundamental so it is included in our empirical assessment - as Edward does in his. We use the country's productivity in manufacturing relative to the US (Rprodm) as a proxy. It is to be expected that relative productivity gains in the tradable sector result in real appreciation (and a negative coefficient for Rprodm). ${ }^{22}$ This assumes that the tradable sector is the main source of productivity gains and that its prices are tied down by the world price level and the exchange rate. ${ }^{23}$ However, regarding the second condition, during the period of import-substitution industrialisation in the middle decades of the last century, the tradable sector in the LA6 tended to be sheltered from foreign competition - with the intensity of this effect varying among the countries. ${ }^{24}$ As a result the "non-tradability" of manufacturing is likely to weaken the link between its productivity performance and the real exchange rate.

Trade policy is proxied by the gross trade ratio (Open). Note that Open can reflect other influences beyond trade policy with different implications for the expected sign of the link. For instance, a natural resource discovery is likely to result in a higher trade share - due to both the development of the new export activity and the increased import capacity - and an RER appreciation (as demonstrated in the Dutch-disease model). Finally, we rely on two limited proxies for public spending on non-tradable goods: total government spending as a share of GDP (Govexp) and non-equipment investment as a share of GDP (Inont). The former proxy is too gross, including both spending on tradable and non-tradable goods; whereas the latter, although targeting non-tradable spending, is too narrow as it

\footnotetext{
20 This definition differs from the symmetric concept used in the paper. This is a common mismatch in the literature dealing with RER in small, open economies as the theory usually defines the RER as the ratio of tradable over non-tradable goods (e.g., Dornbusch, 1980; Swan, 1960; Díaz-Alejandro, 1965), while the empirical work is dominated by the use of the symmetric measure - for which data are usually available. Edwards (1989) and Baffes et al. (1999) are cases in point. However, although this may potentially be a problem as both concepts are not interchangeable, any practical implications for the analysis of the LA6 are mitigated by the existence of a high correlation - on average, of about 0.85 - over the last century between a proxy of the definition used in the model (a real import exchange rate) and the symmetric measure (see Astorga, 2007, p. 41).

21 Other modelling work focusing on developing economies includes a similar set of fundamentals. For instance Wood (1991), Montiel (1999) - on which Baffes et al. (1999) draw, Richaud et al. (2003) - and Rodriguez (1994).

${ }^{22}$ A change in the intra-country relative productivity in non-tradable goods has an opposite effect, therefore undermining the effect emanating from the tradable sector. This may have played a role during the last three decades when the information technology revolution is likely to have boosted the productivity in US services relative to those in the LA6.

23 Overall, the evidence on the role of the B-S effect is mixed (Sarno and Taylor, 2002).

24 There were three main stages in terms of development strategies. First, an export-led growth episode came to an end with the collapse of commodity prices and capital flows in the 1930s. This led to a wave of devaluations and protectionism which shifted relative prices in favour of domestic industries and agricultural production. This transition gave way to a more conscious industrialisation strategy, the so-called import-substitution industrialisation model. Then, gradually, policymakers started to give greater emphasis to export promotion. Balance of payments and fiscal difficulties in the 1970s made the opening of trade more pressing in many countries. The debt crisis and subsequent economic reforms pushed the economies further into a new period of export-led growth.
} 
only includes the investment component. The effect of Govexp depends on whether it took place in the tradable or non-tradable goods sector. To the extent that spending is directed towards non-tradable goods, there should be a real appreciation. Meanwhile, Inont should mostly reflect spending on nontradable goods and thus is expected to be negatively correlated with REER.

\subsection{Error-correction model (ECM)}

Our empirical specification is expressed in terms of a standard ECM that includes both the middle to long-term explanatory power of the fundamentals together. The ECM is specified as follows:

$$
\begin{aligned}
& \operatorname{REER}^{*}=k \mathrm{X}_{t} \\
& \Delta \operatorname{REER}_{t}=b_{0}+\alpha\left(\operatorname{REER}_{-} \mathrm{REER}^{*}\right)_{t-1}+b_{i} \Delta \mathrm{X}_{t}+c \Delta \mathrm{REER}_{t-1}+e_{t}
\end{aligned}
$$

where $\mathrm{REER}_{t}$ is the real effective exchange rate (in logs), $\mathrm{X}_{t}$ a set of fundamentals (in logs), $k$ is a vector of long-run multipliers of REER with respect to $\mathrm{X}_{t}$. Meanwhile, $\Delta$ stands for the first-difference operator, an asterisk indicates equilibrium values and $e_{t}$ is the error term.

Eq. (5) describes the equilibrium or co-integration relationship between the REER and its fundamentals. Eq. (6) includes the feedback or error-correction coefficient $(\alpha)$. It should be negative to indicate that REER deviations from its long-run determinants result in a move back towards equilibrium, and its size $(-1<\alpha<0)$ measures the speed of this adjustment. The feedback coefficient captures the adjustment that takes place both via relative prices and as a result of changes in exchange rate policy (e.g., a devaluation) and its size depends on the structural features of the economy and on institutional factors such as wage indexation rules and the exchange rate regime. This offers an alternative measure of mean reversion (in this case, reversion to the long-run equilibrium path) ${ }^{25}$; which can be compared to the unit-root outcome. Finally, the short-run impact coefficients $\left(b_{i}\right)$ measure the effect of contemporaneous or lagged changes in the fundamentals on $\Delta$ REER $_{t}$.

\subsection{Estimation issues}

The validity of inferences with the above specification depends on meeting two conditions: first, that the series in (5) are co-integrated; and, secondly, that the fundamentals are weakly exogenous for the parameters of interest $k$ and $\alpha$ (Engle et al., 1983). Lack of co-integration means that the model can be estimated in first differences without the need of imposing a long-term relationship; whereas a failure of weak exogeneity indicates that the use of a single-equation framework is not the most appropriate and that variables are better treated as endogenous in a system setting. ${ }^{26}$

We perform the Johansen co-integration test (including structural break dummies as described below in footnote ${ }^{28}$ ). In all six countries the null hypothesis of no co-integration is rejected at least at the 5\% significance level. In two cases (Brazil and Colombia) the test detects at most two co-integrating equations and only one in the remaining four. We restrict attention to the case of a single co-integration relationship, with the causality running from the fundamentals to the REER - as specified by (5). This has the advantage that the long-run parameters are clearly related to the economic theory that underpins the model (Baffes et al., 1999).

Regarding causality, given that we are dealing with small, open economies, we can assume that the terms of trade are exogenous, entering Eq. (5) contemporaneously. ${ }^{27}$ The proxies for public spending on non-tradables are treated as policy variables entering with a lag, making them pre-determined. To

\footnotetext{
${ }^{25}$ The expression to calculate the corresponding half-life values is $t=\log (0.5) / \log (1-\alpha)$; where $t$ is the number of years and $\alpha$ is the feedback coefficient.

${ }^{26}$ This would imply, for instance, using a structural vector error-correction model (e.g., Gauthier and Tessier, 2002; Jang and Ogaki, 2004).

27 Although some countries were able to have some influence in their terms of trade. For instance, Brazil with the coffee valorisation policies in the period 1880-1930 and Chile with saltpetre during a similar period (Abreu and Fernandes, 2005) and, more recently, Venezuela after 1973 via OPEC quota policies.
} 
address a potential reverse-causation problem between REER and Open we tested for weak exogeneity by estimating the feedback coefficient $\eta$ in the following equation:

$$
\Delta \text { Open }_{t}=b_{0}+\eta\left(\text { REER }- \text { REER }^{*}\right)_{t-1}+b_{i} \Delta \mathrm{X}_{t}+c \Delta \text { REER }_{t-1}+e_{t}
$$

If $\alpha$ is significant in (6) and $\eta$ lacks significance in (7), it can be concluded that REER does not contribute to the explanation of the parameters of the equation for $\Delta \operatorname{Open}_{t}$. The outcome of this test (not shown) indicates that, for the purpose of estimating the ECM, Open can be treated as an exogenous variable. Meanwhile, because we use interpolated series for the economically active population in the construction of Rprodm, it is not possible to conduct the weak exogeneity test in this case - not to include $\Delta$ Rprodm $_{t}$ in (6). For the purpose of this exercise relative productivities are instrumented with the used of one period lagged values (the lag also captures a likely delayed impact on relative prices).

We estimate the ECM using a two-stage procedure (Engle and Granger, 1987). First, we run the longterm regressions (5); then, the resulting residuals lagged one period are incorporated into the dynamic model (6). We test for structural breaks in the co-integration errors by applying the Z\&A method described earlier. In those cases where a break is detected we add dummy variables to the respective regression and test again for stationarity in the residuals - a requirement for the series to be cointegrated. Note that we are not automatically adding structural break dummies already identified in the REER series, as some of them are accounted for by the fundamentals. ${ }^{28}$

\subsection{Regression outcome}

Regressions are run for each country over the whole sample in order to determine the explanatory power of the fundamentals and estimate the error-correction term - and its corresponding half-life value. The results of the co-integrating country regressions are summarised in the upper part of Table 4. Since all variables are in natural logs, the coefficients can be interpreted as elasticities of the REER with respect to its fundamentals.

Broadly speaking, the evidence across the six economies is in line with the predictions for the action of the fundamentals. TofT coefficients have all the expected signs and are statistically significant except in the case of Mexico. ${ }^{29}$ As expected, Open is negatively correlated to the REERs with the exception of Chile, and there are little differences between the coefficients of the regressions for each country. As to intra-country variations, the "commodity lottery" ${ }^{30}$ provides a primary source of differences and similarities in the LA6: oil in Venezuela and Mexico, coffee in Brazil and Colombia, copper in Chile and grains and meat in Argentina. This lottery is set to be an influential factor in the RER behaviour of the LA6. First, via their impact on the terms of trade and the external accounts, ${ }^{31}$ and indirectly, through their implications for fiscal policy, particularly in mining and oil economies where the commodity revenues are a major contributor to the budget. Thus, the smaller coefficients for TofT in the oil economies of Mexico and Venezuela could reflect the fact that oil prices were relatively stable up to the mid 1970s (as until then they were under the control of the main oil multinationals); whereas, those economies relying on agricultural products tend to show higher exposure to terms of trade fluctuations over the whole century.

\footnotetext{
${ }^{28}$ The structural dummies added are: Argentina in 1953 of the mean type $(\mathrm{m})$; Brazil in $1944(\mathrm{~m})$; Chile in 1947 of the trend type $(t)$; Colombia in $1983(t)$; Mexico in $1932(\mathrm{~m})$ and $1977(\mathrm{~m})$; and Venezuela in $1961(t)$. Most of the dates for these dummies match the breaks dates identified during the unit-root analysis.

${ }^{29}$ Joyce and Kamas (2003) found that terms of trade changes were the most important determinant of RER movements in Argentina, Colombia and Mexico during the period 1976-1995. And this prominent explanatory role is also consistent with the findings in Cashin et al. (2004) for 53 commodity-dependent developing countries in the period 1980-2002.

${ }^{30}$ The term refers to the joint effect of the magnitude, timing, stability, and product composition of exports (Díaz-Alejandro, 1984). It conveys the idea that each country's exportable resources are largely determined by geography and chance and that their attributes influence the economic performance, the political economy and the institutional fabric.

31 Country regressions, where the terms of trade are explained by the dominant commodity over the whole century and the US whole price index (as proxy for each country's import price index), explain more than half the variations of the dependent variable. And the fit improves considerable by changing the main commodity in different periods (e.g., using saltpetre in Chile during the pre-WWII period, and then copper afterwards) and/or by adding a second commodity (results available on request).
} 
Table 4

Error-correction model regressions.

\begin{tabular}{|c|c|c|c|c|c|c|c|}
\hline \multicolumn{2}{|c|}{ Dependent var. } & $\frac{\text { Argentina }}{\text { REER }}$ & $\begin{array}{l}\text { Brazil } \\
\text { REER } \\
\end{array}$ & $\begin{array}{l}\text { Chile } \\
\text { REER }^{\mathrm{b}} \\
\end{array}$ & $\begin{array}{l}\text { Colombia } \\
\text { REER }\end{array}$ & $\frac{\text { Mexico }^{\mathrm{a}}}{\text { REER }^{\mathrm{b}}}$ & $\begin{array}{l}\text { Venezuela } \\
\text { REER }\end{array}$ \\
\hline \multirow[t]{8}{*}{$\begin{array}{l}\text { Eq. (5); vars. } \\
\text { in logs }\end{array}$} & $\begin{array}{l}\text { Rprodm } \\
\text { (lagged) }\end{array}$ & -0.14 & -0.36 & -0.21 & 0.29 & 0.25 & 0.15 \\
\hline & Open (lagged) & 0.04 & -0.74 & 0.17 & -0.89 & $\underline{0.06}$ & -0.31 \\
\hline & TofT $_{t}$ & -0.35 & -0.24 & -0.14 & -0.42 & $\overline{-0.11}$ & -0.12 \\
\hline & $\begin{array}{l}\text { Govexp/ } \\
\text { Inont }_{t-1}\end{array}$ & 0.00 & 0.14 & -0.23 & -0.14 & -0.13 & 0.12 \\
\hline & Adjusted $R^{2}$ & 0.73 & 0.79 & 0.80 & 0.90 & 0.76 & 0.87 \\
\hline & SER & 0.111 & 0.181 & 0.165 & 0.135 & 0.093 & 0.093 \\
\hline & Error term $(\alpha)$ & -0.43 & -0.22 & -0.19 & -0.20 & -0.24 & -0.29 \\
\hline & $\begin{array}{l}\text { Half-life } \\
\text { equivalent }^{c}\end{array}$ & 1.2 & 2.8 & 3.3 & 3.1 & 2.5 & 2.0 \\
\hline \multirow{10}{*}{$\begin{array}{l}\text { Eq. (6); vars. } \\
\text { in growth } \\
\text { rates }\end{array}$} & $\Delta$ Open $_{\mathrm{t}}$ & -0.01 & 0.02 & -0.16 & -0.26 & -0.43 & -0.04 \\
\hline & $\Delta$ Tof $_{\mathrm{t}}$ & -0.14 & -0.18 & $\overline{0.06}$ & -0.20 & 0.28 & -0.05 \\
\hline & $\begin{array}{l}\Delta \text { Govexp }_{\mathrm{t}} / \\
\Delta \text { inont }_{\mathrm{t}}\end{array}$ & -0.04 & 0.01 & -0.07 & 0.04 & -0.05 & $\overline{-0.01}$ \\
\hline & $\Delta \mathrm{REER}_{\mathrm{t}-1}$ & 0.15 & 0.13 & -0.02 & 0.46 & 0.16 & 0.16 \\
\hline & Dummies for & $38(+), 49(-)$ & 06(-), 21(+), & $21(+), 32(+)$ & $03(-), 32(+)$ & $32(+), 49(+)$ & $61(+), 85(-)$ \\
\hline & outliers & $52(-) 56(+)$ & $31(+) 35(+)$ & $72(-) 74(+)$ & $40(+) 58(+)$ & $54(+) 82(+)$ & $88(-) 95(-)$ \\
\hline & years (sign) & $58(-), 64(-)$ & $53(+), 58(+)$ & $85(+)$ & $59(-), 86(+)$ & $86(+), 95(+)$ & $96(+), 97(-)$ \\
\hline & & $\begin{array}{l}67(+), 79(-) \\
82(+)\end{array}$ & $89(-), 99(+)$ & & & & \\
\hline & Adjusted $R^{2}$ & 0.70 & 0.62 & 0.57 & 0.56 & 0.80 & 0.59 \\
\hline & SER & 0.069 & 0.097 & 0.096 & 0.079 & 0.058 & 0.064 \\
\hline
\end{tabular}

Constant terms and structural dummy are included in the regressions but not shown.

a $1925-2000$.

b uses Inont; coefficients in bold are significant at the $5 \%$ level, and in bold underline at $10 \%$ level. SER: standard error of regression.

${ }^{c}$ Calculated as $t=\log (0.5) / \log (1-|\alpha|)$; where $t$ is the number of years that takes to dissipate $50 \%$ of the deviation from equilibrium.

The role of Rprodm is less clear. The B-S hypothesis is supported in the case of Argentina, Brazil and Chile, but the remaining countries show positive and significant coefficients. Although this could be attributed to departures from the model's assumptions, there is no obvious explanation for the differences across the LA6. Moreover, the lack of price data discriminating between tradable and nontradable goods makes it difficult to know whether the problem lies in the link between productivity and the relative price of non-tradables or in the workings of the law of one price - or in both. ${ }^{32}$ Also mixed is the evidence of government spending, but in this case it is likely to reflect the limitations of the proxies at hand. Govexp is negatively correlated with the REER in Colombia, and Inont proved significant and with a negative coefficient in Chile and Mexico. Otherwise, both variables were either positively correlated or failed to be significant.

Following Parsley and Popper (2001) we explore the potential for non-linearities in the ECM model by adding a term that results from multiplying the lagged REER deviation by its absolute value - which preserves sign changes. If larger REER misalignment induces a faster reversion then the coefficient $\alpha_{2}$ in the following regression should be significant and negative:

$$
\begin{aligned}
\Delta \operatorname{REER}_{t}= & b_{0}+\alpha_{1}\left(\operatorname{REER}_{-} \mathrm{REER}^{*}\right)_{t-1}+\alpha_{2}\left(\mathrm{REER}_{-}-\mathrm{REER}^{*}\right)_{t-1}\left|\left(\operatorname{REER}-\mathrm{REER}^{*}\right)_{t-1}\right| \\
& +b_{i} \Delta \mathrm{X}_{t}+c \Delta \mathrm{REER}_{t-1}+e_{t} .
\end{aligned}
$$

\footnotetext{
${ }^{32}$ For instance, Engel (1999) in his study of the US RER relative to other developed countries found little evidence for the role of non-tradable relative prices in explaining RER movements.
} 
In general, we found no evidence supporting the case for non-linear behaviour when estimating (8). However, this cannot be taken as conclusive evidence against non-linearities in the adjustment process as the outcome may be sensitive to the specification used. ${ }^{33}$

During the estimation of (6) some dummies were added in order to deal with outliers in the residuals. The dates unusually coincide - either the same year or the next - with major trade reforms (some of which may not be captured in OPEN) and episodes of maxi-devaluations (e.g., of 50\% or larger) which, in a number of cases, were part of a reform in the exchange rate regime. For instance, reflecting trade reforms, there are added dummies in Argentina (1958, 1979), Brazil (1935, 1958, 1989), Chile (1985), Colombia (1932, 1940, 1959), Mexico (1949, 1954, 1995) and Venezuela (1985); whereas others are needed to avoid distortions generated by maxi-devaluation in Argentina (1956,1967, 1982), Brazil (1921,1931, 1999), Chile (1921, 1932, 1985), Colombia $(1903,1958)$, Mexico $(1932,1949,1982)$ and Venezuela $(1961,1996) .{ }^{34}$ In some cases, such as Brazil (1953), Chile (circa1974), Mexico (1995) and Venezuela (1991) there was a combination of the three factors: change in regime, trade reform and maxi-devaluation. Note that the inclusion of these dummies for outliers has the potential to reduce the speed of adjustment measured by the feedback coefficients, so that our ECM regressions are likely to produce conservative half-life estimates.

We also included dummies in (6) to control for potential distortions to the speed of adjustment associated with hyperinflation and multiple exchange rates. In both cases, and for all countries, they proved not to be significant at the $5 \%$ level and with little impact on the estimated feedback coefficients (results not shown).

\subsection{Half-life results revisited}

The lower section of Table 4 presents the outcome of estimating (6). All the feedback coefficients proved to be statistically significant at the $5 \%$ level or lower and with the right sign. We also include the half-life values implied by the $\alpha$ s, ranging from 1.2 years in Argentina to 3.3 years in Chile, with an LA6 average of $2 \frac{1}{2}$ years. ${ }^{35}$ The comparison with the adjusted unit-root half-life values (see Table 3 ) shows similar results for Argentina (1.2 years with ECM vs. 1.4 years with unit-root) and Venezuela (2.0 vs. 1.9), but these are significantly higher for Brazil(2.8 vs.1.3), Chile (3.3 vs.1.2), Colombia (3.2 vs. 2.1) and Mexico ( 2.5 vs. 1.2 ). The LA6 half-life average for the ECM is $2 \frac{1}{2}$ years compared with $1 \frac{1}{2}$ years for the adjusted unit-root series. However, if the latter are corrected by a small-sample bias, the gap could shorten to only half a year (2.5 vs. 2.0). What to make of the variation of half-life estimates by country? Ideally, the ECM should provide half-life values that reflect better the changing nature of the equilibrium position than the unit-root estimates, where a linear trend is used as a proxy for those changes. However, in practice, it is a moot point the extent to which those variations are the consequence of employing a more accurate approach or are just the result of specification problems. Perhaps the true value lies in between.

Regarding inter-country variations, although the terms of trade proved to be a key explanatory variable for the LA6, the dominant commodity does not seem to have been a main source for systematic differences in persistence among the LA6 - though a more rigorous testing is needed. The average half-lives estimated for the oil economies of Mexico and Venezuela (2.2 years with ECM and 1.6 years with unit-root) are comparable to those of the coffee economies of Brazil and Colombia ( 3 and 1.7); while the average for the mining economies (2.6 and 1.5) are roughly in line with those of the agriculture-based economies (2.4 and 1.6).

Other potential sources of differences, such as undergoing hyperinflation or the prominence of multiple exchange rates, equally do not appear to result in country variations in speed of adjustment. The average half-lives for Argentina, Brazil and Chile in both cases (2.4 and 1.3) are not dissimilar to the average of the remaining three countries (2.6 and 1.8). Differences in the adjustment process can also

\footnotetext{
33 For instance, a more comprehensive analysis using smooth transition autoregressive models (STAR) as in Lothian and Taylor (2008), or a more detailed assessment differentiating the type of exchange rate regime in place, as in Parsley and Popper (2001), may give different result.

34 As expected the sign of the dummies associated with maxi-devaluations are positive (as they trigger a real depreciation), while those linked to trade reform are mixed as they include both moves of trade liberalisation and trade protection on the RER.

${ }^{35} \mathrm{Kim}$ et al. (2003) cast doubts on the interpretation of half-life values derived from reduced-form ECMs (and their comparability to unit-root based values) as they may not recover the structural parameters. However, in our case, evidence of weak exogeneity in key fundamentals means that the estimated alphas should reflect the structural speed of adjustment.
} 
be attributed to institutional factors such as the rigidity of wages and prices, the cost of labour mobility or the availability of capital flows to cushion adjustment. But their specific role in each of the LA6 is beyond the scope of this work.

\section{Conclusions}

Our unit-root analysis of real multilateral exchange rates in the six leading Latin American economies over the last century found a very slow process of mean reversion - if any - in the original series in levels. This means that the strict PPP hypothesis is rejected. This contrasts with the results of longspan studies focusing on developed economies that found evidence of mean reversion in the unadjusted RER series. Moreover, we showed that the initial non-stationarity can be removed by making allowances for trends and structural breaks. The required adjustment can give an insight into a potentially significant sample bias in long-run studies that concentrate on more advanced economies. In our six Latin American countries, the half-life of the adjusted series ranges from 1.2 years in Chile to 2.1 years in Colombia.

The presence of structural breaks and trend behaviour in the unit-root analysis indicates a timevarying RER equilibrium position and the need to model explicitly the role of macroeconomic fundamentals. The outcome with the error-correction specification also shows a reversion, but in this case to a conditional mean defined by the co-integrating relationship. It broadly confirms the prediction that the equilibrium REER is determined by its fundamentals, and that their inclusion significantly reduces measured persistence. Terms of trade coefficients and, to some extent, those of trade openness, proved significant and with the expected signs; whereas the evidence is mixed for relative productivities and real public spending. The half-life values implied by the feedback coefficients range from 1.2 years in Argentina to 3.3 years in Chile. These estimates are robust to the inclusion of dummies to control for potential distortions associated with hyperinflation and multiple exchange rates.

Overall, despite differences in the approach followed and potential misspecification problems in both methods (e.g., assumed linearity, selection of break dates, use of proxies, or omitted variables), our half-life estimates are within the range of those reported in the long-span studies (after correcting by breaks) focusing on developed countries. The average half-lives for the LA6 ranges from $1 \frac{1}{2}$ years when the unit-root approach is used - a value that could go up to about 2 years if a correction for smallsample size is applied - to a conservative estimate of $2 \frac{1}{2}$ years under the ECM model. However, these estimates, although lower than the 3-5 year range that motivated the Rogoffs puzzle, still indicate the presence of important obstacles to the adjustment process (e.g., owing to structural rigidities in reallocating resources after an external shock; or delays in policy response) that need further investigation.

The failure to reject the unit-root hypothesis in the series in levels and the support found for a changing equilibrium position has important practical implications for the construction of PPP benchmarks for international income comparisons. For instance, it undermines the use of a constant PPP benchmark in long-span studies involving these countries (Astorga et al., 2005), or a wider sample of economies including the LA6 (Prados de la Escosura, 2004; Maddison, 1989). It also raises questions on the use of PPP exchange rate estimates to determine the degree of misalignment of the nominal exchange rate and the appropriate policy response (Sarno and Taylor, 2002), at the time that confirms the importance of taking into account permanent shifts in key fundamentals such as the terms of trade and trade policy to inform decisions on exchange rate policy.

As to the wider implications for development and economic convergence, our time-series analysis of the RERs in the LA6 indicates a depreciating trend over the last century (although some countries experienced appreciation during the 1900-1950 period or so). This behaviour is in line with evidence found in studies covering a much wider sample of developing countries during the second half of the century or so. A pattern that is consistent with lack of economic convergence, a phenomenon that would call for faster productivity growth in those countries attempting to catch up and real exchange rate appreciation over time. However, we did not find conclusive evidence for the role of relative productivities or support for the Balassa-Samuelson effect, a result that requires further research. 


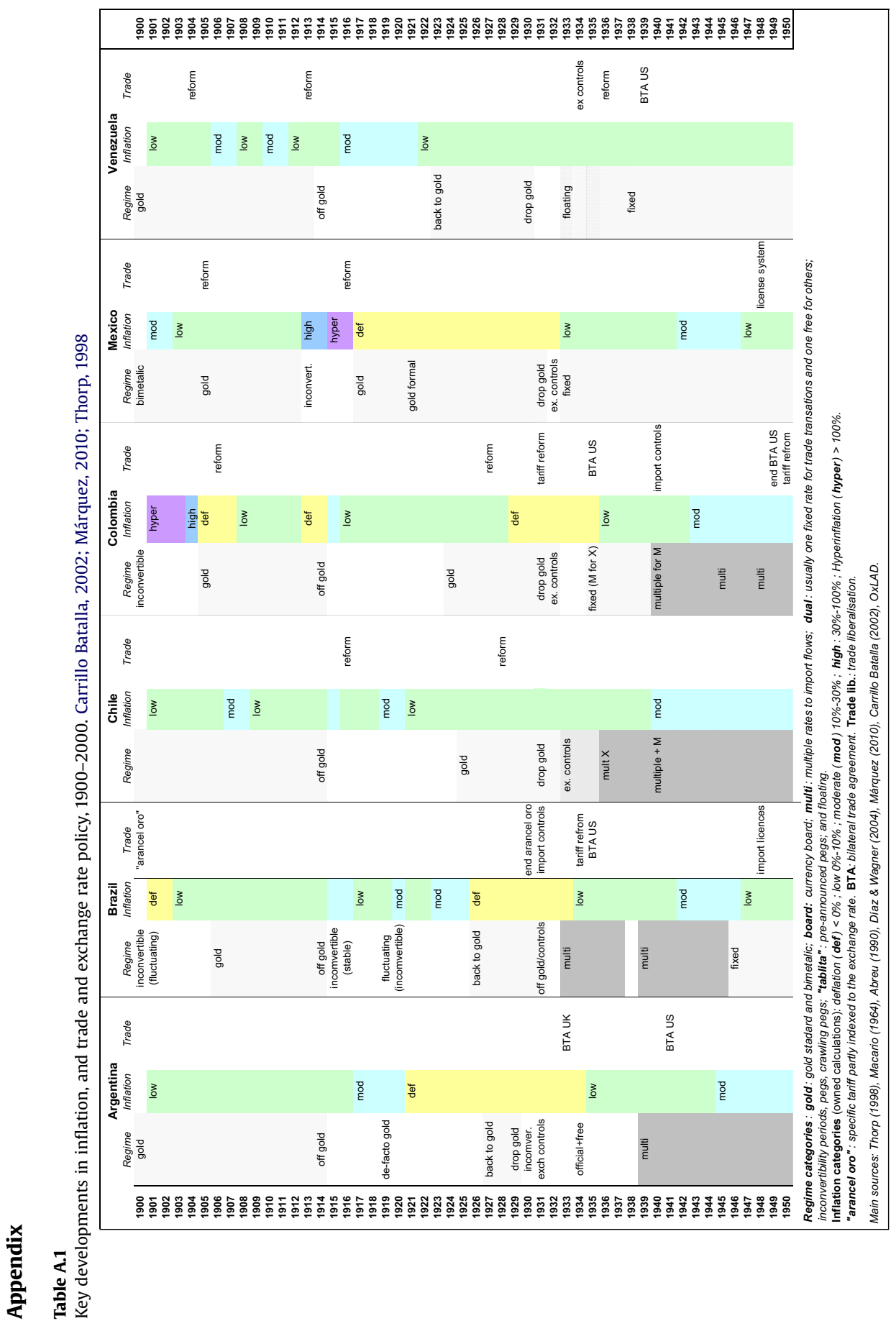




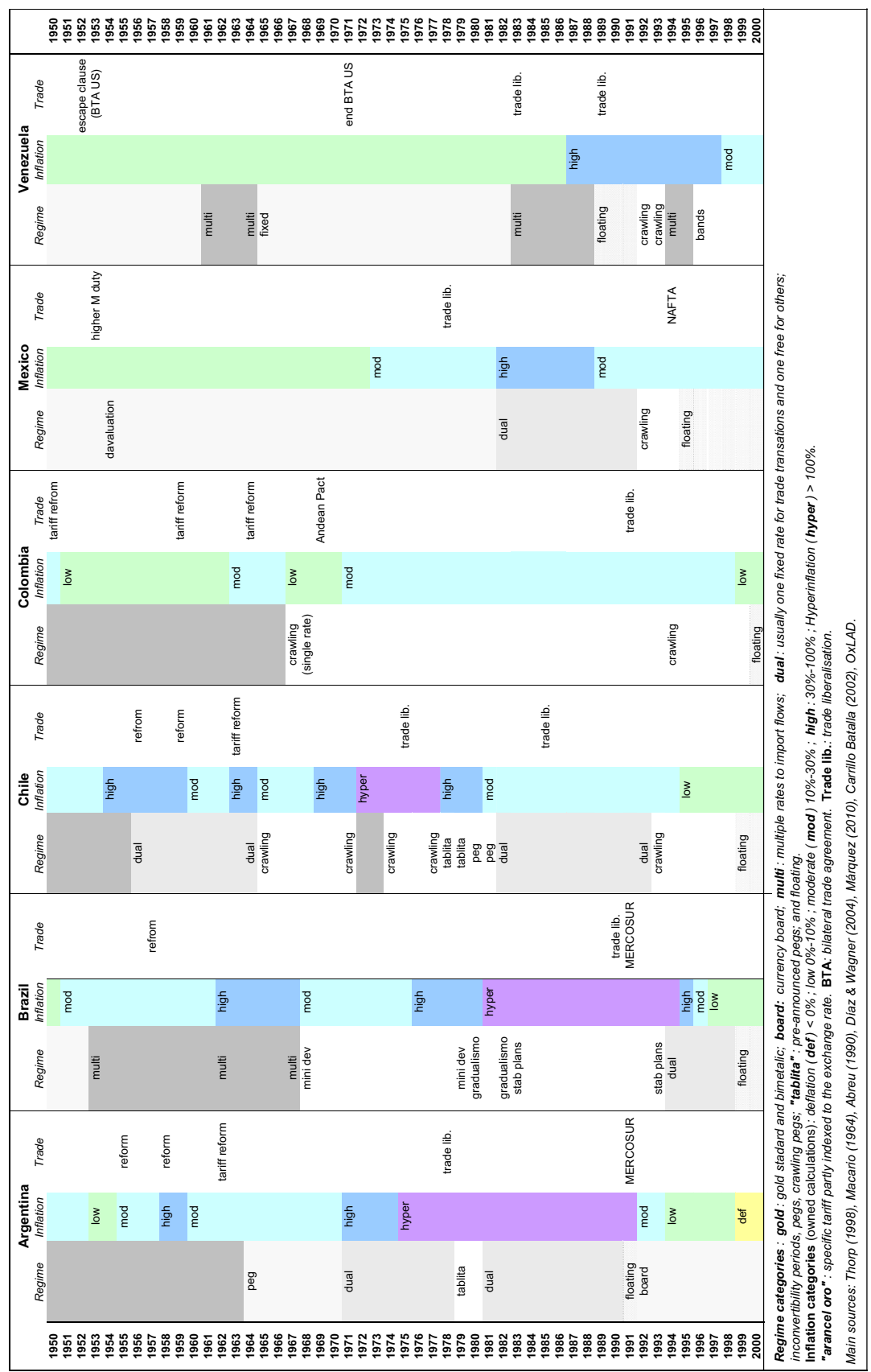


Table A.2

Real effective exchange rates PPP (symmetric) definition (index, $1950=100$ ).

\begin{tabular}{|c|c|c|c|c|c|c|c|c|c|c|c|c|c|}
\hline & Argentina & Brazil & Chile & Colombia & Mexico & Venezuela & & Argentina & Brazil & Chile & Colombia & Mexico & Venezuela \\
\hline 1900 & 126.3 & 149.7 & 113.6 & 150.0 & 41.6 & 124.9 & 1950 & 100.0 & 100.0 & 100.0 & 100.0 & 100.0 & 100.0 \\
\hline 1901 & 140.2 & 141.4 & 118.3 & 148.6 & 34.2 & 126.1 & 1951 & 107.6 & 94.8 & 100.2 & 112.4 & 91.4 & 101.3 \\
\hline 1902 & 129.4 & 122.4 & 113.1 & 175.5 & 38.8 & 138.5 & 1952 & 81.7 & 91.4 & 96.9 & 123.0 & 83.2 & 101.6 \\
\hline 1903 & 133.1 & 117.3 & 99.8 & 116.1 & 39.9 & 143.6 & 1953 & 64.7 & 165.8 & 99.7 & 115.3 & 80.6 & 103.1 \\
\hline 1904 & 132.2 & 108.9 & 98.2 & 87.6 & 34.1 & 139.5 & 1954 & 61.8 & 192.6 & 84.0 & 105.6 & 96.8 & 103.3 \\
\hline 1905 & 122.6 & 123.6 & 97.7 & 95.6 & 31.5 & 137.6 & 1955 & 59.1 & 185.0 & 76.0 & 132.2 & 92.6 & 103.1 \\
\hline 1906 & 122.6 & 81.1 & 116.8 & 111.6 & 32.4 & 125.3 & 1956 & 105.2 & 164.1 & 98.2 & 140.8 & 90.2 & 105.1 \\
\hline 1907 & 121.6 & 87.1 & 99.8 & 126.6 & 34.6 & 137.9 & 1957 & 132.5 & 155.1 & 110.4 & 155.6 & 87.4 & 108.5 \\
\hline 1908 & 120.5 & 85.5 & 106.2 & 117.8 & 32.5 & 140.7 & 1958 & 112.5 & 237.4 & 110.2 & 209.9 & 84.5 & 105.9 \\
\hline 1909 & 111.8 & 90.8 & 99.5 & 109.1 & 30.9 & 139.5 & 1959 & 121.4 & 216.2 & 109.4 & 186.7 & 84.1 & 100.8 \\
\hline 1910 & 108.7 & 81.6 & 96.2 & 110.6 & 27.3 & 128.6 & 1960 & 129.9 & 221.2 & 100.2 & 178.3 & 80.7 & 102.9 \\
\hline 1911 & 109.0 & 81.8 & 94.0 & 104.6 & 27.5 & 118.3 & 1961 & 121.8 & 242.5 & 96.2 & 171.9 & 80.2 & 140.6 \\
\hline 1912 & 111.2 & 79.0 & 106.8 & 94.1 & 28.8 & 118.9 & 1962 & 129.3 & 233.6 & 92.9 & 169.2 & 80.8 & 142.9 \\
\hline 1913 & 115.6 & 89.3 & 105.9 & 99.3 & 29.3 & 122.1 & 1963 & 127.6 & 201.5 & 108.8 & 170.1 & 81.9 & 143.7 \\
\hline 1914 & 118.5 & 99.1 & 110.6 & 114.8 & 29.5 & 122.5 & 1964 & 102.7 & 241.3 & 98.4 & 159.6 & 80.5 & 141.9 \\
\hline 1915 & 127.2 & 115.6 & 116.5 & 111.4 & 30.9 & 117.2 & 1965 & 101.2 & 235.7 & 102.6 & 165.6 & 79.8 & 143.2 \\
\hline 1916 & 120.5 & 106.5 & 122.9 & 124.3 & 34.0 & 117.8 & 1966 & 110.5 & 205.7 & 109.3 & 193.9 & 79.6 & 144.3 \\
\hline 1917 & 119.9 & 103.9 & 112.3 & 145.4 & 39.7 & 125.1 & 1967 & 145.3 & 195.4 & 117.9 & 200.4 & 79.7 & 148.5 \\
\hline 1918 & 122.1 & 120.7 & 111.7 & 153.4 & 45.8 & 113.4 & 1968 & 141.4 & 203.8 & 129.3 & 216.1 & 80.0 & 150.4 \\
\hline 1919 & 129.4 & 108.0 & 136.9 & 138.6 & 50.4 & 125.0 & 1969 & 138.6 & 213.6 & 137.6 & 221.8 & 80.9 & 154.0 \\
\hline 1920 & 129.1 & 110.3 & 134.0 & 153.7 & 53.4 & 126.4 & 1970 & 140.8 & 221.1 & 142.4 & 236.3 & 81.9 & 160.1 \\
\hline 1921 & 156.8 & 175.2 & 166.4 & 149.4 & 51.0 & 152.6 & 1971 & 131.2 & 229.5 & 131.2 & 238.3 & 81.7 & 161.0 \\
\hline 1922 & 147.0 & 160.1 & 144.1 & 135.7 & 56.8 & 142.9 & 1972 & 145.1 & 239.3 & 98.7 & 248.3 & 82.8 & 169.2 \\
\hline 1923 & 147.2 & 154.5 & 137.4 & 121.1 & 54.3 & 142.1 & 1973 & 126.8 & 223.7 & 130.8 & 244.1 & 80.5 & 179.1 \\
\hline 1924 & 141.7 & 130.8 & 149.4 & 106.3 & 56.8 & 139.7 & 1974 & 117.7 & 208.0 & 197.4 & 237.2 & 72.5 & 180.7 \\
\hline 1925 & 125.8 & 104.4 & 139.9 & 102.1 & 55.1 & 132.5 & 1975 & 105.2 & 192.2 & 207.1 & 264.0 & 69.0 & 178.9 \\
\hline 1926 & 136.3 & 103.8 & 131.2 & 87.8 & 57.2 & 126.5 & 1976 & 119.7 & 186.9 & 186.6 & 247.0 & 71.1 & 176.6 \\
\hline 1927 & 132.0 & 134.0 & 131.1 & 79.1 & 59.8 & 131.8 & 1977 & 150.8 & 187.7 & 156.8 & 226.7 & 94.4 & 184.9 \\
\hline 1928 & 131.2 & 117.5 & 128.6 & 73.1 & 60.6 & 132.7 & 1978 & 141.7 & 206.1 & 172.5 & 230.6 & 92.4 & 192.4 \\
\hline 1929 & 131.0 & 123.4 & 104.8 & 79.5 & 61.0 & 137.7 & 1979 & 100.8 & 226.8 & 172.2 & 210.9 & 84.9 & 182.9 \\
\hline 1930 & 140.8 & 142.5 & 98.7 & 95.6 & 59.2 & 144.1 & 1980 & 87.3 & 255.0 & 143.2 & 207.0 & 74.1 & 167.4 \\
\hline 1931 & 149.5 & 209.4 & 100.6 & 98.0 & 59.2 & 153.3 & 1981 & 100.8 & 226.1 & 125.0 & 199.5 & 66.5 & 152.5 \\
\hline 1932 & 135.6 & 169.4 & 234.7 & 106.2 & 85.7 & 157.8 & 1982 & 127.8 & 202.3 & 144.1 & 193.2 & 100.6 & 142.0 \\
\hline 1933 & 127.5 & 175.2 & 191.3 & 139.0 & 93.7 & 146.2 & 1983 & 138.4 & 286.4 & 172.0 & 205.2 & 106.5 & 134.6 \\
\hline 1934 & 135.2 & 173.3 & 211.1 & 173.0 & 99.6 & 120.1 & 1984 & 125.2 & 306.9 & 180.0 & 220.4 & 91.6 & 166.8 \\
\hline 1935 & 125.3 & 250.2 & 220.4 & 195.1 & 100.1 & 132.6 & 1985 & 143.2 & 297.1 & 227.4 & 261.6 & 91.7 & 155.1 \\
\hline 1936 & 123.0 & 254.2 & 218.6 & 193.6 & 98.0 & 132.1 & 1986 & 158.9 & 307.9 & 262.2 & 323.9 & 133.3 & 193.3 \\
\hline 1937 & 107.8 & 216.1 & 200.9 & 176.0 & 84.4 & 114.5 & 1987 & 181.0 & 319.5 & 273.8 & 348.6 & 136.7 & 218.6 \\
\hline 1938 & 152.8 & 226.8 & 189.1 & 172.9 & 99.9 & 109.8 & 1988 & 180.1 & 313.0 & 291.4 & 357.3 & 108.1 & 169.6 \\
\hline 1939 & 158.5 & 249.3 & 182.8 & 154.8 & 106.6 & 106.1 & 1989 & 201.4 & 224.7 & 268.5 & 370.6 & 100.1 & 176.6 \\
\hline 1940 & 144.5 & 220.8 & 157.2 & 160.9 & 105.2 & 104.8 & 1990 & 181.5 & 226.4 & 288.5 & 392.9 & 97.2 & 188.3 \\
\hline 1941 & 150.3 & 207.5 & 157.3 & 174.1 & 94.4 & 113.7 & 1991 & 158.2 & 279.6 & 287.5 & 372.3 & 85.7 & 308.9 \\
\hline 1942 & 130.5 & 194.4 & 137.7 & 176.1 & 93.8 & 118.3 & 1992 & 173.7 & 320.9 & 290.0 & 333.5 & 80.7 & 302.2 \\
\hline 1943 & 127.3 & 176.1 & 134.9 & 156.5 & 83.0 & 114.2 & 1993 & 165.2 & 321.8 & 288.9 & 323.9 & 76.5 & 280.8 \\
\hline 1944 & 123.8 & 146.3 & 138.7 & 129.6 & 66.4 & 107.8 & 1994 & 167.3 & 285.5 & 286.0 & 295.8 & 79.7 & 247.6 \\
\hline 1945 & 126.1 & 136.0 & 133.6 & 119.4 & 64.3 & 102.7 & 1995 & 181.3 & 242.5 & 257.8 & 293.1 & 116.4 & 206.0 \\
\hline 1946 & 116.2 & 126.8 & 129.8 & 122.7 & 58.9 & 107.5 & 1996 & 184.2 & 220.5 & 248.9 & 264.9 & 103.4 & 261.7 \\
\hline 1947 & 121.8 & 127.9 & 105.7 & 118.9 & 65.2 & 112.6 & 1997 & 184.1 & 215.2 & 237.3 & 252.2 & 89.8 & 216.1 \\
\hline 1948 & 115.2 & 128.8 & 100.8 & 112.9 & 72.1 & 111.7 & 1998 & 185.7 & 220.8 & 248.4 & 276.5 & 90.0 & 186.1 \\
\hline 1949 & 93.7 & 113.2 & 86.0 & 120.2 & 100.7 & 101.8 & 1999 & 159.0 & 313.6 & 257.8 & 300.9 & 81.2 & 165.9 \\
\hline \multirow[t]{6}{*}{1950} & 100.0 & 100.0 & 100.0 & 100.0 & 100.0 & 100.0 & 2000 & 163.1 & 300.2 & 273.0 & 335.0 & 75.6 & 164.4 \\
\hline & & & & & & & 2001 & 158.1 & 349.0 & 284.2 & 351.7 & 69.2 & 157.0 \\
\hline & & & & & & & 2002 & 276.3 & 328.3 & 281.2 & 370.0 & 71.9 & 193.2 \\
\hline & & & & & & & 2003 & 256.5 & 303.3 & 297.5 & 409.3 & 92.0 & 204.2 \\
\hline & & & & & & & 2004 & 267.0 & 286.3 & 277.2 & 361.5 & 100.6 & 205.9 \\
\hline & & & & & & & 2005 & 284.2 & 237.6 & 252.4 & 310.0 & 97.1 & 204.7 \\
\hline
\end{tabular}




\section{Data sources and methodology notes}

Unless otherwise indicated data comes from OxLAD.

Real bilateral exchange rates. Argentina. 1900-92: uses the series "real exchange rate imports" from Veganzones and Winograd (1997). We multiply this series by the ratio CPIus/WPIus to obtain our RER\$1 series. 1993-2005: uses growth rates of an RER index obtained from nominal exchange rate (NER) and price data. Chile. Own calculations using data from Díaz et al. (2005). Our real bilateral rate uses average inflation rather than year-end values, and our multilateral rates comprise five trading partners in addition to the US and the UK. Colombia. 1900-05 \& 2000-2005: own estimates using NER and price data (see below). Otherwise, uses GRECO's RER series without tariff. For Brazil, Mexico and Venezuela we construct series from NER and price data.

Nominal exchange rate (local currency per USS). Argentina. OxLAD, official rate. Brazil. 1900-33 \& 1938 from Abreu (1990). During these years there was a unified rate. In 1934 we use the controlled rate; and in 1935-37 \& 1939-46, the "taxas de câmbio livre" - which was applied to imports. For 1947-2000 we employ IPEA's commercial exchange rates. Chile. Díaz et al. (2005), except in 1932-33 from Lüders (1968). In 1900-30 we use the official rate, and in 1960-2000 annual averages of the rate applied to banking transactions. During the period of multiple exchange rates (1936-1956) the calculation reflects a weighted average of the rates (Díaz and Wagner, 2004; 11). Colombia. 1900-04: the exchange rate peso/US\$ is calculated based on the peso/sterling parity (López Mejía, 1990). 1905-30: uses GRECO (2002). 1931-74: uses a weighted average of the rate applied to imports (Romero Baquero, 2005). The series is completed forward by applying growth rates of GRECO's series - which mostly reflects rates applied to trade-account flows. Mexico. OxLAD for 1900-80, except in 1915-17 when estimates from Cárdenas and Manns (1987) are used. After 1981: uses Banco de México - in ITAM (2004). Venezuela. Izard (1970) in 1900-37 \& BCV (2000) thereafter. During the episodes with differentiated rates for imports (1960-64; 1983-89; \& 1994-95) we use simple averages of the rates applied to imports.

With the exception of Argentina, the parallel or market-determined exchange rate between 1950 and 1999 comes from Reinhart and Rogoff (2004). The sources for 1900-50 are: Brazil, "taxa de câmbio livre" from Abreu (1990); Chile, market rate from Díaz et al. (2005); Colombia, rate applicable to shortterm capital flows from Romero Baquero (2005); and Mexico, market rate from ITAM (2004).

Domestic price indices and inflation. Argentina.1900-80: uses OxLAD. 1980 onwards: CEI. Brazil. For the sake of inter-temporal consistency we chose the implicit GDP deflator estimated by IBGE (2003) as our measure for the internal price index. Chile. 1900-27: Mamalakis (1983). 1928-2000: Instituto Nacional de Estadísticas (INE). During 1970-77 the INE series is corrected using Cortazar and Marshall (1980). 1971-72: inflation in 1971 is calculated by applying the same adjustment used by Díaz et al. (2005) in their Dec.-Dec. series. For 1972 we assume a correction factor that reflects the lower acceleration in annual inflation relative to the year-end values. Colombia. 1900-05: inflation estimates from López Mejía (1990). GRECO thereafter. Mexico. 1900-13: WPI in Mexico City from ITAM (2004). During 1915-17 inflation grows in line with currency depreciation (from Cárdenas and Manns, 1987). 1918 onwards: OxLAD. Venezuela. 1900-44: general price index from Baptista (1997). After 1945: CPI from BCV.

Import weights (calculated as the ratio of annual import values to the total). Argentina. Mitchell (1993) for 1900-51; IMF Historical Trade Statistics (HTS) for 1952-80; and CEI for 1990-2000. 198090: figures are interpolated. Japan data in 1929, 1932, 1936 and 1937 come from US Tariff Commission (1942). Countries included: France, Germany, Japan, UK, US (G5 hereinafter), and Brazil. Brazil. IBGE (2003), except 1938-47 from Mitchell (1993). Countries included: G5 and Argentina. Chile. Mitchell (1993) for 1900-51 and IMF/HTS for 1952-80; with the exception of US and UK' weights in 1900-60 from Díaz et al. (2005). After 1990 data comes from ECLAC and Servicio Nacional de Aduanas. 1980-90: interpolated. Import shares from Brazil prior to 1950s are assumed to be zero. Countries included: G5, Argentina, and Brazil. Colombia. Mitchell (1993) for 1900-51 \& 1988; IMF/HTS for 1952-80; and DANE for 1994-2000. 1980-87 \& 1989-93: interpolated. Import shares from Venezuela prior to 1926 are assumed to be $0.6 \%$ (1926-28 average) and from Brazil prior to 1941 to be $0.1 \%$. Countries included: G5, Venezuela, and Brazil. Mexico. Mitchell (1993) for 1900-47; IMF/HTS for 1948-80; and INEGI thereafter. 1914-19: interpolated. Import values from the US and the rest of Latin America during 1900-11 \& 1932-79 from ITAM (2004). Countries included: G5, and rest of Latin America. Venezuela. Mitchell 
(1993) for 1900-47 \& 1988; IMF/HTS for 1948-80. Weights for US, UK, and Germany in 1920-29 are from Machado \& Padrón, (1987, 82). After 1993 uses ECLAC and CEI. 1980-87 \& 1989-93: interpolated. Import shares from Colombia and Brazil prior to 1948 are assumed to be $0.4 \%$ (1948 value) and Brazil prior to 1948 to be $0.1 \%$, respectively. Countries included: G5, Colombia, and Brazil. Note: with the exception of Brazil and Argentina, import data between the LA6 and Japan start circa 1950. In such cases we assume that import flows from Japan during the first half of the century were insignificant.

RER-related data on third countries. France. The CPI in 1900-89 is from Maddison (1991), and IMFIFS thereafter. We use Officer (2002) for the NER to the US\$. Germany. The CPI in 1900-59 comes from Mitchell (1993), and IMF/IFS thereafter. We use Officer (2002) for the NER to the US\$. Japan. The CPI in 1900-60 comes from Maddison (1991), and IMF/IFS thereafter. We use Officer (2002) for the NER to the US\$ after 1916. UK. Index of producer prices 1900-70 is from Mitchell (1993), and IMF thereafter. CPI (retail price index) is from McCuster (2001). We use Officer (2001) for the rate US\$ per sterling. US. PPI in 1900-12 is from USDC (1975) and in 1913-2000 from BLS (2002). CPI for 1900-70 from Mitchell (1993), and IMF thereafter. We use Officer (2001) for the US\$/sterling rate.

Net barter terms of trade. We use OxLAD for Argentina, Colombia, Mexico, and Venezuela. Brazil is sourced from IBGE (2003) and Chile from Díaz et al. (2005).

Labour productivity in manufacturing relative to the US. Own calculations from OxLAD. In the following years the series grow in line with relative overall productivity: Brazil 1900-19; Chile 190007; Colombia 1900-24; Venezuela 1900-35. There is no data for Mexico between 1911 and 1920.

Gross trade share as \% of GDP (Openness). The procedure to construct the trade ratios is as follows: i) applies growth rates of export and import quantum indices to exports and imports dollar values in 1970s; ii) applies growth rates of GDP series at constant prices to the GDP dollar value in 1970; iii) adds up the resulting export and import series and divide them by the GDP series (multiplied by 2). Export quantum. Brazil: IBGE (2003); Chile: Díaz et al. (2005); Mexico: the revolution gap is filled in with values of the series of export of goods at constant dollars (export values deflated by the unit value of exports). Import quantum. Argentina: before 1910 figures are calculated from import series at constant dollars. Brazil: IBGE (2003); Chile: Díaz et al. (2005); Colombia: GRECO (2002) for 1905 onwards. Before 1905 uses imports at constant dollars. Venezuela: from 1920 onwards uses an index based on imports from national accounts at 1968 prices (Baptista, 1997). Prior to 1920 uses import series at constant dollars.

Non-machinery investment spending. 1900-94: calculated form data in Hofman (2000), and from official sources thereafter. Government spending as \% of GDP. Calculated from data in OxLAD.

\section{References}

Abreu, M. de P. (Ed.), 1990. A Ordem do Progresso - Cem Anos de Política Econômica Republicana. Campus, Rio de Janeiro. Abreu, M. de P., Fernandes, F.T., 2005. Market Power and Commodity Prices: Brazil, Chile and the United States, 1820 s-1930. Texto para Discussão 511. Departamento de Economia PUC-Rio.

Adler, M., Lehmann, B., 1983. Deviations from purchasing power parity in the long run. Journal of Finance 38, 1471-1487.

Andrews, D., 1993. Exactly median-unbiased estimation of first order autoregressive/unit root models. Econometrica 61,139-165.

Astorga, P., 2007. Real Exchange Rates in Latin America: What Does the 20th Century Reveal? DHEI Working Papers in Economic History Universidad Carlos III, Madrid.

Astorga, P., Bergés, A.R., Fitzgerald, E.V.K., 2005. The standard of living in Latin America during the twentieth century. The Economic History Review 59, 765-796.

Baffes, J., Elbadawi, I., O’Connel, S., 1999. Single-equation estimation of the equilibrium real exchange rate. In: Hinkle, L., Montiel, P. (Eds.), Exchange Rate and Measurement for Developing Countries. Oxford University Press, pp. 405-464.

Bai, J., Perron, P., 1998. Estimating and testing linear models with multiple structural changes. Econometrica 66, 47-78.

Balassa, B., 1964. The purchasing-power parity doctrine: a reappraisal. Journal of Political Economy 72, 584-596.

Balli, O., Murray, C.M., Papell, D.H., 2009. Median-unbiased Estimation of Structural Change Models: an Application to PPP. University of Houston Working Paper.

Banco Central de Venezuela, BCV, 2000. Series Estadísticas de Venezuela (1940-1999). Banco Central de Venezuela, Caracas. Go to: http://www.bcv.org.ve/c2/indicadores.asp.

Baptista, A., 1997. Bases Cuantitativas de la Economía Venezolana, 1830-1995. Ediciones Fundación Polar, Caracas.

Bureau of Labor Statistics, BLS, 2002. Producer Price Indexes. Go to: http://www.bls.gov/ppi.

Cárdenas, E., Manns, C., 1987. Inflation and monetary stabilization in Mexico during the revolution. Journal of Development Economics 27, 275-294.

Carrillo Batalla, T.E., 2002. Cuentas Nacionales de Venezuela. 1874-1914. Colección Económico Financiera, Banco Central de Venezuela.

Cashin, P., Cespedes, L.F., Sahay, R., 2004. Commodity currencies and the real exchange rate. Journal of Development Economics 75 (1), 239-268. 
Centro de Economía Internacional, CEI. Government of Argentina. http://cei.mrecic.gov.ar.

Chinn, M., 2006. A primer on real effective exchange rates. Open Economies Review 17, 115-143.

Clark, P.B., MacDonald, R., 1998. Exchange Rates and Economic Fundamentals - A Methodological Comparison of BEERs and FEERs. IMF Working Papers 98/67. International Monetary Fund.

Cortazar, R., Marshall, J., 1980. Indice de precios al consumidor en Chile: 1970-1978. In: Colección Estudios CIEPLAN, vol. 4. CIEPLAN, Santiago.

Díaz, J., Wagner, G., 2004. Política comercial: instrumentos y antecedentes. Chile en los siglos XIX y XX. Documento de trabajo 223. Instituto de Economía, Pontificia Universidad Católica de Chile.

Díaz, J., Lüders, R., Wagner, G., 2005. Chile 1820-2000: La República en Cifras. Santiago.

Díaz-Alejandro, C.F., 1965. Exchange Rate Devaluation in a Semi-industrialized Country. The MIT Press, Cambridge, MA.

Díaz-Alejandro, C.F., 1984. Latin America in the 1930s. In: Thorp, R. (Ed.), Latin America in the 1930s: The Role of the Periphery in World Crisis. Macmillan/St Antony's College, Oxford, pp. 315-352.

Dornbusch, R., 1980. Open Economy Macroeconomics. Basic Books, New York.

Economic Commission for Latin America and the Caribbean, ECLAC, various years. Statistical Yearbook for Latin America (SYLA). UN: New York, NY.

Edwards, S., 1989. Real Exchange Rates, Devaluation and Adjustment: Exchange Rate Policy in Developing Countries. The MIT Press, Cambridge, MA.

Edwards, S., van Wijnbergen, S., 1987. Tariffs, the real exchange rate and the terms of trade: on two popular propositions in international economics. Oxford Economic Papers 39, 458-464.

Enders, W., 1988. Arima and cointegration tests of PPP under fixed and flexible exchange rate regimes. Review of Economics and Statistics 70, 504-508.

Engel, C.M., 1999. Accounting for U.S. real exchange rate changes. Journal of Political Economy 107, 507-538.

Engle, R.F., Granger, W.J., 1987. Co-integration and error correction: representation, estimation, and testing. Econometrica 55, 251-276.

Engle, R.F., Hendry, D.F., Richard, J.-F., 1983. Exogeneity. Econometrica 51, 277-304.

Frankel, J.A., Rose, A.K., 1996. A panel project on purchasing power parity: mean reversion within and between countries. Journal of International Economics 40, 209-224.

Froot, K.A., Rogoff, K., 1995. Perspectives on PPP and long-run real exchange rates. In: Grossman, G., Rogoff, K. (Eds.), Handbook of International Economics, vol. 3, pp. 1647-1688.

Gauthier, C., Tessier, D., 2002. Supply shocks and real Exchange Rate Dynamics: Canadian Evidence. Working Paper 02-31, Bank of Canada.

Grupo de Estudios del Crecimiento Económico, GRECO, 2002. El Crecimiento Económico Colombiano en el Siglo XX. Banco de la República, Fondo de Cultura Económica, Bogotá.

Hegwood, N.D., Papell, D.H., 1998. Quasi purchasing power parity. International Journal of Finance and Economics 3, $279-289$.

Hofman, A., 2000. The Economic Development of Latin America in the Twentieth Century. Edward Elgar Publishing, Northampton, MA.

Instituto Brasileiro de Geografía e Estadística, IBGE, 2003. Estatísticas do Século XX. IBGE, Rio de Janeiro. Go to: http://www. ibge.gov.br/seculoxx.

Instituto Nacional de Estadística Geografía e Informática, INEGI, 1990. Estadísticas Históricas de México. INEGI, Mexico City.

Instituto Nacional de Estadísticas de Chile, INE. http://www.ine.cl/.

Instituto de Pesquisa Econômica Aplicada. Go to. http://www.ipeadata.gov.br.

Instituto Tecnológico Autónomo de México, ITAM, 2004. Estadísticas Históricas de México. Go to: http://biblioteca.itam.mx/ recursos/ehm.html\#sector.

International Monetary Fund, IMF. Directory of Trade Statistics Historical Database, 1948 to 1980. IMF: Washington, DC.

International Monetary Fund, IMF IFS, 2002. International Financial Statistics. IMF, Washington, DC.

Izard, M., 1970. Series Estadísticas para la Historia de Venezuela. Publicaciones ULA, Mérida.

Jang, K., Ogaki, M., 2004. The effects of monetary policy shocks on exchange rates: a structural vector error correction model approach. Journal of Japanese and International Economies 18, 99-114.

Joyce, J., Kamas, L., 2003. Real and nominal determinants of real exchange rates in Latin America: short-run dynamics and longrun equilibrium. The Journal of Development Studies 39, 155-182.

Kim, J., Ogaki, M., Yang, M., 2003. Structural Error Correction Models: Instrumental Variables Methods and an Application to an Exchange Rate Model. RCER Working Papers 502.

López Mejía, A., 1990. La estabilización de la economía colombiana después de la guerra de los mil días y el período de transición monetaria comprendido entre 1903 y 1923. In: López, A., Meisel, A. (Eds.), El Banco de la República. Antecedentes, Evolución y Estructura. Banco de la República, Bogotá.

Lothian, J.R., Taylor, M.P., 1996. Real exchange rate behavior: the recent float from the perspective of the past two centuries. Journal of Political Economy 104, 488-509.

Lothian, J.R., Taylor, M.P., 2008. Real exchange rates over the past two centuries: how important is the Harrod-BalassaSamuelson effect? The Economic Journal 118, 1742-1763.

Lüders, R., 1968. A monetary history of Chile, 1925-1958. Doctoral dissertation, Department of Economics, The University of Chicago (unpublished).

Macario, S., 1964. Proteccionism and Industrialization in Latin America. Economic Bulleting of Latin America IX, 61-101.

MacDonald, R., 1998. What Do We Really Know About Exchange Rates? Working Papers 28 Oesterreichische National Bank.

Machado de Acedo, C., Padrón, M., 1987. La Diplomacia de López Contreras y el Tratado de Reciprocidad Comercial con los Estados Unidos. Ministerio de Relaciones Exteriores, Caracas.

Maddison, A., 1989. The World Economy in the Twentieth Century. OECD, Paris.

Maddison, A., 1991. Dynamic Forces in Capitalist Development: a Long-run Comparative View. Oxford University Press, Oxford. Mamalakis, M., 1983. Historical Statistics of Chile: Money, Prices, and Credit Services, vol. 4. Greenwood Press, London.

Márquez, G., 2010. From Fiscal Revenue to Industrial Promotion. Tariffs in Mexico, 1870-1916. El Colegio de México, mimeo.

McCuster, J.J., 2001. What Was the Inflation Rate Then? Economic History Services, EH.Net. 
Mitchell, B.R., 1993. International Historical Statistics: The Americas, 1750-1988. Macmillan, Basingstoke.

Montiel, P., 1999. Determinants of the long-run equilibrium exchange rate: an analytical model. In: Hinkle, L., Montiel, P. (Eds.), Exchange Rate Misalignment: Concepts and Measurement for Developing Countries. World Bank, OUP, Oxford, pp. 264-290.

Neary, J.P., 1988. Determinants of the equilibrium real exchange rate. American Economic Review 78, 210-215.

Officer, L.H., 2001. Exchange Rate Between the United States Dollar and the British Pound, 1791-2000. Go to:. Economic History Services, EH.Net http://www.eh.net/hmit/exchangerates/pound.php.

Officer, L.H., 2002. Exchange Rate Between the United States Dollar and Forty Other Countries, 1913-1999. Go to:. Economic History Services, EH.Net http://eh.net/hmit/exchangerates/.

Oxford Latin American Economic History Database, OxLAD. The Latin American Centre, Oxford University. Go to: http://oxlad. qeh.ox.ac.uk/.

O’Connell, A., 1984. La Argentina en la depresión: los problemas de una economía abierta. Desarrollo Económico 23 (92), 479-514.

Parsley, D.C., Popper, H., 2001. Official exchange rate arrangements and real exchange rate behaviour. Journal of Money, Credit and Banking 33 (4), 976-993.

Perron, P., 1989. The great crash, the oil price shock, and the unit root hypothesis. Econometrica 57, 1361-1401.

Perron, P., 1990. Testing for a unit root in a time series with a changing mean. Journal of Business and Economic Statistics 8,153-162.

Perron, P., 2006. Dealing with structural breaks. In: Patterson, K., Mills, T.C. (Eds.), Palgrave Handbook of Econometrics: Econometric Theory, vol. 1. Palgrave Macmillan, pp. 278-352.

Perron, P., Vogelsang, T.J., 1993. The great crash, the oil price shock and the unit root hypothesis: erratum. Econometrica 61, 248-249.

Prados de la Escosura, L., 2004. When Did Latin America Fall Behind? Evidence from Long-run International Inequality. Universidad Carlos III, Madrid. Working Papers in Economic History.

Reinhart, C.M., Rogoff, K.S., 2004. The modern history of exchange rate arrangements: a reinterpretation. The Quarterly Journal of Economics 119, 1-48.

Richaud, C., Varoudakis, A., Veganzones, M.-A., 2003. Real exchange rate and openness in emerging economies: Argentina in the long run. Applied Economics 35, 293-303.

Rodriguez, C.A., 1994. The external effects of public sector déficits. In: Easterly, W., Rodriguez, C.a., Schmidt-Hebbel, K. (Eds.), Public Sector Deficits and Macroeconomics Performance. Oxford University Press, Oxford.

Rogoff, K., 1996. The purchasing power parity puzzle. Journal of Economic Literature 34, 647-668.

Romero Baquero, C.A., 2005. El Tipo de Cambio en Colombia 1932-1974. Doctoral dissertation. Universidad Autónoma de Barcelona. Barcelona.

Sager, M., 2006. Explaining the persistence of deviations from PPP: a non-linear Harrod-Balassa-Samuelson effect? Applied Financial Economics 16, 41-61.

Samuelson, P.A., 1964. Theoretical notes on trade problems. Review of Economics and Statistics 46, 145-154.

Sarno, L., Taylor, M.P., 2002. Purchasing Power Parity and the Real Exchange Rate. In: IMF Staff Papers, vol. 49(1). International Monetary Fund.

Servicio Nacional de Aduanas of Chile. Go to: http://www.aduana.cl/p4_principal.

Swan, T., 1960. Economic control in a dependent economy. Economic Record 36, 51-66.

Taylor, A.M., 2002. A century of purchasing power parity. Review of Economics and Statistics 84, 139-150.

Taylor, M.P., 2003. Purchasing power parity. Review of International Economics 11, 436-452.

Taylor, M.P., 2004. Is official exchange rate intervention effectieve? Economica 71, 1-11.

Taylor, M.P., Peel, D.A., Sarno, L., 2001. Nonlinear mean-reversion in real exchange rates: toward a solution to the purchasing power parity puzzles. International Economic Review 42 (4), 1015-1042.

Thorp, R., 1998. Progress, Poverty and Exclusion: An Economic History of Latin America in the 20th Century. Inter-American Development Bank, John Hopkins University Press, Baltimore, MD.

Trujillo, G., 2006. Programa F - Secuenciales Zivot\&Andrews. Universidad Científica del Sur, Lima.

United States Department of Commerce, USDC, 1975. Historical Statistics of the United States. United States Department of Commerce, Washington, DC.

United States Tariff Commission, 1942. The Foreign Trade of Latin America. R146. Washington DC.

Veganzones, M.-A., Winograd, C., 1997. Argentina in the 20th Century: An Account of Long-awaited Growth. Development Centre of the OECD, Paris.

Wood, A., 1991. Global trends in real exchange rates 1960-1984. World Development 19, 317-332.

Zivot, E., Andrews, D.W.K., 1992. Further evidence on the great crash, the oil-price shock and the unit-root hypothesis. Journal of Business and Economic Statistics 10, 251-270. 